\title{
Unprecedented convergent synthesis of the fused tricyclic thiophenes via Friedel-Crafts cycliacylation reactions
}

\author{
Hassan A. K. Abd El-Aal* and Ali A. Khalaf \\ Chemistry Department, Faculty of Science, Assiut University, Assiut, 71516, Egypt \\ E-mail: hassankotb33@yahoo.com
}

Received 01-24-2019

Accepted 05-14-2019

Published on line $05-20-2019$

\section{Abstract}

An efficient and concise procedure toward benzo-and pyridothieno[2,3-b] fused N-heterocycles from readily available substrates is described. The process involves Lewis and Bronsted acids-mediated Friedel-Crafts cyclizations of the synthesized thiophene-based carboxylic acid precursors into new tricyclic thiophenes. The method efficiently achieves the promising pharmaceutically polycyclic thiophenes in good yields.<smiles>CCOC(=O)c1c(N)sc(-c2ccccc2)c1C</smiles>

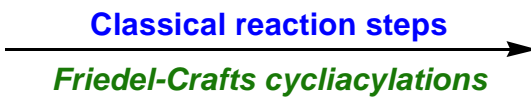

- 6 examples up to $85 \%$ yield

- intresting ring closures

- high functional group potential

- simple and mild reaction conditions

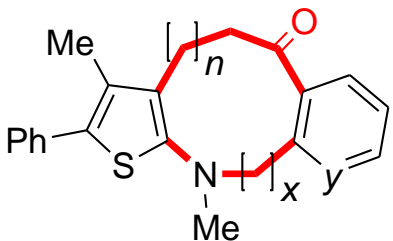

a: $\mathrm{n}=0, \mathrm{x}=0, \mathrm{y}=\mathrm{CH} ; \mathbf{b}: \mathrm{n}=0$, $x=1, A r=C H ; c: n=0, x=1$, $\mathrm{Ar}=\mathrm{N} ; \mathbf{d}: \mathrm{n}=1, \mathrm{x}=0, \mathrm{y}=\mathrm{CH}$; e: $n=1, x=1, y=C H ; f: n=1$, $x=1, y=N$

Keywords: Friedel-Crafts cycliacylations, thiophenes, thienoazocines, heteropolycycles 


\section{Introduction}

Thiophenes and their fused heterocyclic derivatives have garnered much attention in the organic synthetic community due to their wide abundance in many biological active natural products ${ }^{1}$ and pharmaceutical drugs $^{2}$ e.g. olanzapine, ticarcillin, urothione, biotin, clopidogrel, tienopramine and pizotifen (Fig 1). Both natural and synthetic thiophene architectures are particularly noted for their immense biological properties ${ }^{3}$ like anticonvulsant, anticholinergic, potent analgesic, antipsychotic, anti-inflammatory, antihistaminic, antidepressant, antidiabetic and anti-HIV activities. Moreover, functionalized thiophenes have also found application in industry as luminescent and light-emitting materials, ${ }^{4}$ conducting polymers ${ }^{5}$ and antioxidant. ${ }^{6}$

Some of the most relevant synthetic approaches applied in the synthesis of fused thiophenes include well known examples of Paal-Knorr synthesis, ${ }^{7}$ Gewald reaction, ${ }^{8}$ Fiesselmann synthesis, ${ }^{9}$ Lawesson's reagent ${ }^{10}$ and Hinsberg synthesis. ${ }^{11}$ Most of the reported methods imply a stepwise introduction of the fused five or sixmembered heterocyclic rings in a multistep synthesis. As a result of the structural diversity and astonishing biological profile of thiophene-based heterocycles, synthetic chemists have sought to organize and design versatile methods towards the discovery of novel drug architectures. ${ }^{12}$
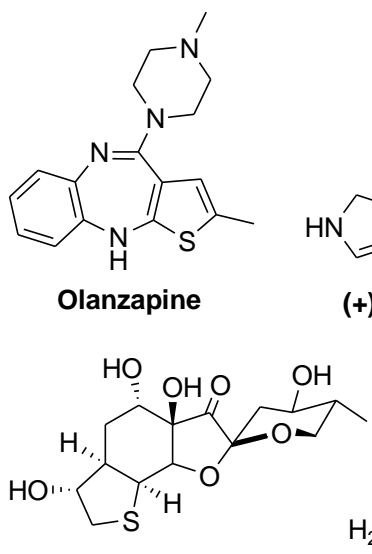

Breynolide

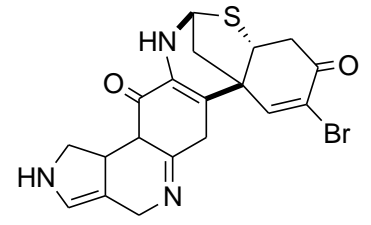

(+)-Discorhabdine A

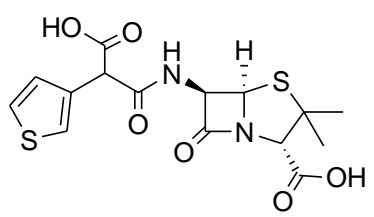

Ticarcillin

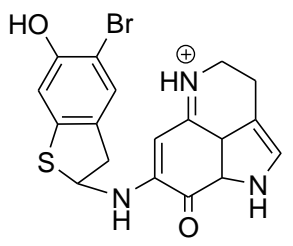

Makaluvamine F

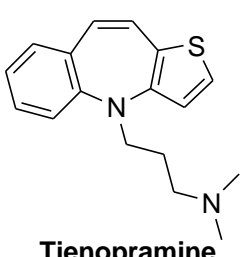

Tienopramine<smiles>COC(=O)[C@H](c1ccccc1Cl)N1CCc2sccc2C1</smiles>

Clopidogrel

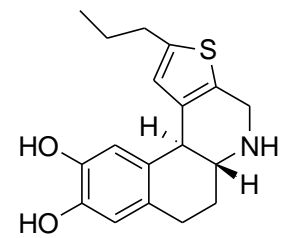

A-86929

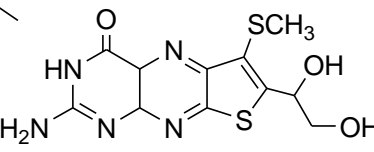

Urothione

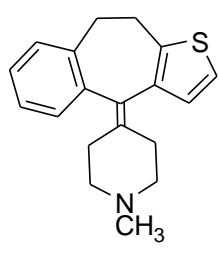

Pizotifen

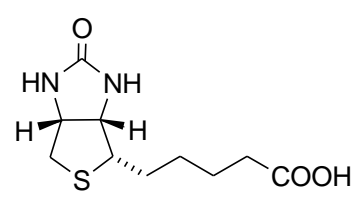

Biotin

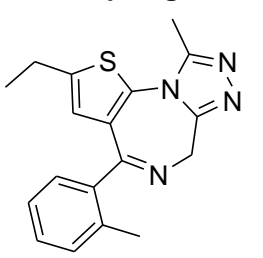

Etizolan

Figure 1. Examples of drugs containing fused thiophenes core structures.

Of particular interest is the formation of hetero-fused thiophene compounds such as thienoquinoline and thienoazepine regioisomers are associated with diverse pharmacological activities. ${ }^{13} \mathrm{~A}$ literature search of the general applied approaches for the synthesis of these scaffolds revealed that, a variety of robust methods for synthesizing and selective functionalization of substituted thienoquinolines with different fusion positions have been reported. ${ }^{14}$ Literately, limited work has been carried out on the synthesis of fused thienoazepines. Whereas thiophenes fused with eight or higher-membered $\mathrm{N}$-heterocyclic rings are thereof not reported in the literature. Synthetic methodologies have been developed to generate thienoazepines and can be divided into three major classes, namely, stepwise construction of thiophene nucleus or fused seven membered $\mathrm{N}$ hetero-rings via cyclizations of acyclic chain elements of appropriate substrates, ${ }^{15}$ photochemical reactions of 
appropriately heterocyclic substrates ${ }^{16}$ and ring expansion reactions of the pre-constructed fused thiophene substrates. ${ }^{17}$

In continuation of our research interests regarding sophistications of an efficient and divergent procedures for synthesis and functionalization of heterocycles, ${ }^{18}$ it was considered worthwhile to synthesize certain new polycyclic thiophenes in moderate to high yields incorporating two bioactive moieties, thiophene and medium sized $\mathrm{N}$-heterocycles in a single molecular designs via $\mathrm{AlCl}_{3} / \mathrm{CH}_{3} \mathrm{NO}_{2}$ or PPA or $\mathrm{P}_{2} \mathrm{O}_{5}$-mediated Friedel-Crafts ${ }^{19}$ cyclizations on thiophene-based carboxylic acids.

\section{Results and Discussion}

We describe herein the synthesis of benzo-and pyrido fused thieno[2,3- $b$ ]azepinones, thieno[2,3- $b]$ azocinones and thieno[2,3-b]azoninones 8a-f from the functionalized thiophene carboxylic acids 7a-f (Schemes 1). For the synthesis of target compounds, first, the substituted thiophene-3-carboxylate $\mathbf{1}^{20}$ was prepared by the literature Gewald's procedure ${ }^{21}$ from ethyl cyanoacetate with phenylacetone in the presence of diethylamine to afford substituted 2-aminothiophene 1.

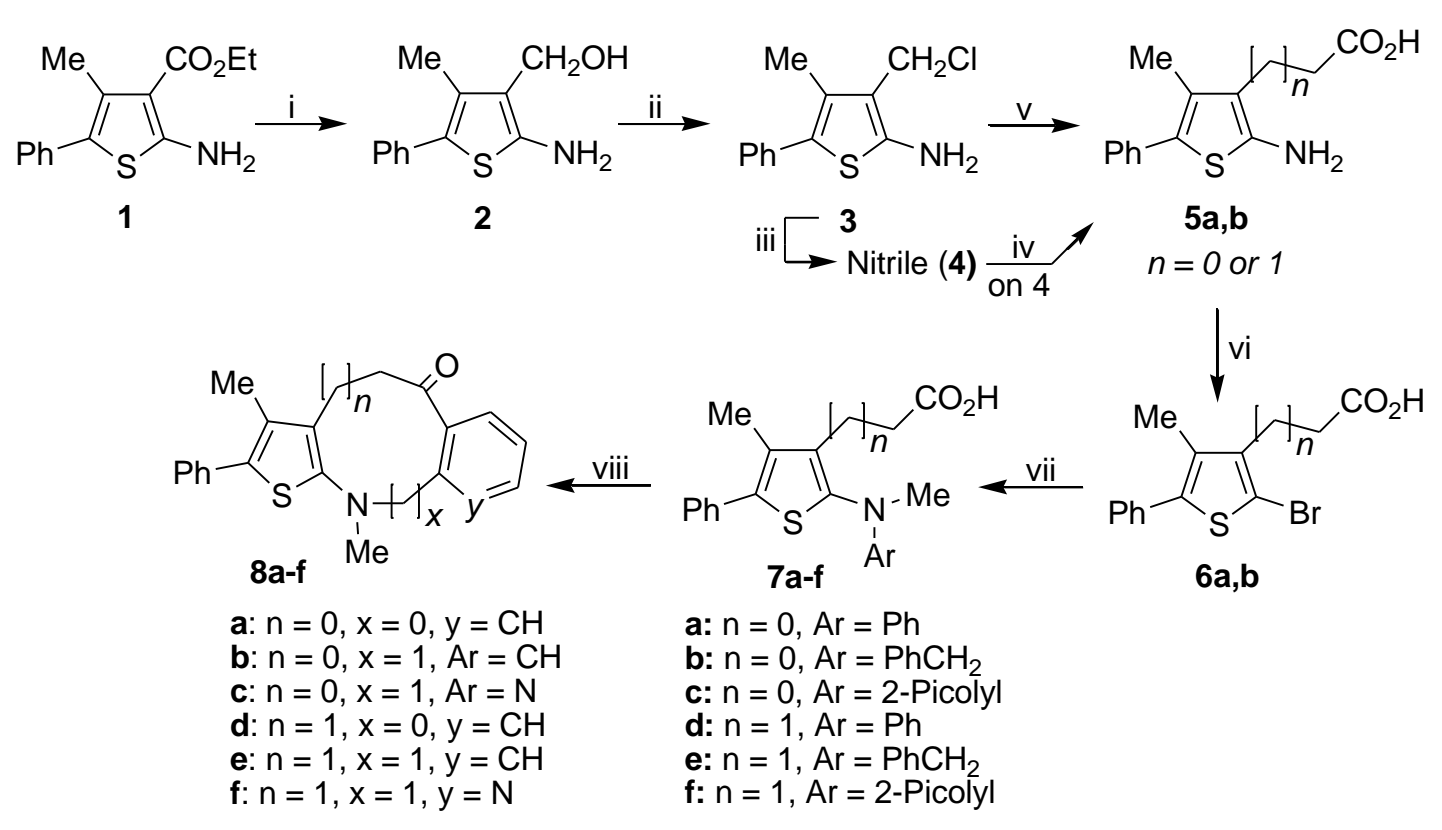

Scheme 1. Reagents and conditions: (i) $\mathrm{LiAlH}_{4} / \mathrm{THF}_{-\mathrm{Et}} \mathrm{O}$, reflux, $6 \mathrm{~h}, \mathrm{NaOH}, 84 \%$, (ii) $\mathrm{SOCl}_{2} / \mathrm{Et}_{2} \mathrm{O}, 2 \mathrm{~h}, \mathrm{reflux}, 90 \%$, (iii) KCN/EtOH, 6h, reflux, 80\%, (iv) EtOH/NaOH, 10h, reflux, $\mathrm{AcOH}, 82 \%$, (v) a. $\mathrm{NaCH}(\mathrm{COOEt}) 2, \mathrm{KOH}, 7 \mathrm{~h}, \mathrm{reflux}$, b. heated at $170-180{ }^{\circ} \mathrm{C}, 10 \mathrm{~min}$., $75 \%$, (vi) $\mathrm{HCl} / \mathrm{NaNO}_{2} / \mathrm{KBr}, 1 \mathrm{~h}, 90-100{ }^{\circ} \mathrm{C}, 70-74 \%$, (vii) Arylations with aromatic amines ( $\mathrm{N}$-methylaniline or $\mathrm{N}$-benzylmethylamine or 2-picolylmethylamine)/ $\mathrm{K}_{2} \mathrm{CO}_{3} / \mathrm{DMF}, 120-130{ }^{\circ} \mathrm{C}$, 10h, (viii) Cycliacylations by $\mathrm{AlCl}_{3} / \mathrm{CH}_{3} \mathrm{NO}_{2}$ or PPA or $\mathrm{P}_{2} \mathrm{O}_{5}$ catalysts (Table 1 )

Reduction of compound 1 with $\mathrm{LiAlH}_{4}$ in THF/Et $2 \mathrm{O}$ afforded alcohol 2 . This alcohol was converted into the corresponding chloride $\mathbf{3}$ using $\mathrm{SOCl}_{2}$. Both acids $\mathbf{5 a}$ and $\mathbf{5 b}$ were obtained starting from chloride $\mathbf{3}$ via two synthetic routes outlined in Scheme 1 . Hence, chloride 3 was converted into nitrile 4 with KCN in ethanol followed by hydrolysis of resulting nitrile with $\mathrm{NaOH}$ to afford the corresponding acetic acid $5 \mathrm{a}$. 
On the other hand, chloride 3 underwent alkylation of malonic ester with EtONa in EtOH to give propionic acid $\mathbf{5 b}$. Once the key intermediates acids $\mathbf{5 a , b}$ were obtained, they can be transformed into bromo-acids $\mathbf{6 a}, \mathbf{b}$ by reaction with $\mathrm{NaNO}_{2} / \mathrm{HCl} / \mathrm{KBr}$. Lastly, arylations of the resulted bromo-acids $\mathbf{6} \mathbf{a}, \mathbf{b}$ with aromatic amines (PhNHMe or $\mathrm{MeNHCH}_{2} \mathrm{Ph}$ or 2-picolylmethylamine) in the presence of $\mathrm{K}_{2} \mathrm{CO}_{3}$ in DMF afforded thiophenebased alkanoic acids 7a-f in good overall yields. The structures of all products were appropriately established by both elemental and spectral analyses. We next attempted to create tricyclic scaffolds 8a-f by performing intramolecular Friedel-Crafts acylations on heterocyclic acids 7a-f. We thought this would be an interesting cyclization due to the diverse potential regiochemical outcomes (Table 1).

Table 1. Efforts to optimize Friedel-Crafts cyclizations on substrates 7a-f.

\begin{tabular}{|c|c|c|c|c|}
\hline Entry & Substrate & Product & Conditions & $\begin{array}{l}\text { Yield } \\
(\%)^{\mathrm{A}} \\
\end{array}$ \\
\hline \multirow{3}{*}{1} & & & $\mathrm{AlCl}_{3} / \mathrm{CH}_{3} \mathrm{NO}_{2}{ }^{\mathrm{B}}, \mathrm{DCM}^{\mathrm{C}}, 14 \mathrm{~h}, \mathrm{rt}$ & 81 \\
\hline & & & $\mathrm{P}_{2} \mathrm{O}_{5}{ }^{\mathrm{D}}, \mathrm{DCE}^{\mathrm{E}}, 14 \mathrm{~h}$, reflux & 78 \\
\hline & $7 a$ & $8 \mathrm{a} \mathrm{Me}$ & $\mathrm{PPA}^{\mathrm{F}}, 6 \mathrm{~h}, 190-200^{\circ} \mathrm{C}$ & 73 \\
\hline \multirow{3}{*}{2} & & & $\mathrm{AlCl}_{3} / \mathrm{CH}_{3} \mathrm{NO}_{2}, \mathrm{DCM}, 13 \mathrm{~h}, \mathrm{rt}$ & 84 \\
\hline & & & $\mathrm{P}_{2} \mathrm{O}_{5}, \mathrm{DCE}, 11 \mathrm{~h}$, reflux & 80 \\
\hline & $7 b$ & $8 \mathrm{~b} \mathrm{Me}$ & PPA, 7 h, $190-200{ }^{\circ} \mathrm{C}$ & 75 \\
\hline \multirow{3}{*}{3} & & & $\mathrm{AlCl}_{3} / \mathrm{CH}_{3} \mathrm{NO}_{2}, \mathrm{DCM}, 12 \mathrm{~h}, \mathrm{rt}$ & 78 \\
\hline & & & $\mathrm{P}_{2} \mathrm{O}_{5}, \mathrm{DCE}, 16 \mathrm{~h}$, reflux & 72 \\
\hline & & 8c Me & PPA, 8 h, $190-200{ }^{\circ} \mathrm{C}$ & 70 \\
\hline \multirow{3}{*}{4} & & & $\mathrm{AlCl}_{3} / \mathrm{CH}_{3} \mathrm{NO}_{2}, \mathrm{DCM}, 11 \mathrm{~h}, \mathrm{rt}$ & 79 \\
\hline & & & $\mathrm{P}_{2} \mathrm{O}_{5}, \mathrm{DCE}, 14 \mathrm{~h}$, reflux & 81 \\
\hline & $7 d$ & $8 d$ & PPA, $10 \mathrm{~h}, 190-200^{\circ} \mathrm{C}$ & 75 \\
\hline \multirow{3}{*}{5} & & & $\mathrm{AlCl}_{3} / \mathrm{CH}_{3} \mathrm{NO}_{2}, \mathrm{DCM}, 20 \mathrm{~h}, \mathrm{rt}$ & 83 \\
\hline & & & $\mathrm{P}_{2} \mathrm{O}_{5}, \mathrm{DCE}, 15 \mathrm{~h}$, reflux & 74 \\
\hline & $7 e$ & $8 \mathrm{e}$ & PPA, 9 h, $190-200{ }^{\circ} \mathrm{C}$ & 75 \\
\hline \multirow{3}{*}{6} & & & $\mathrm{AlCl}_{3} / \mathrm{CH}_{3} \mathrm{NO}_{2}, \mathrm{DCM}, 18 \mathrm{~h}, \mathrm{rt}$ & 85 \\
\hline & & & $\mathrm{P}_{2} \mathrm{O}_{5}, \mathrm{DCE}, 18 \mathrm{~h}$, reflux & 80 \\
\hline & $\mathrm{N}$ & $\dot{\mathrm{Me}}$ & PPA, 8 h, $190-200^{\circ} \mathrm{C}$ & 73 \\
\hline
\end{tabular}

Alsolated yields. ${ }^{\mathrm{B}} \mathrm{With} \mathrm{AlCl}_{3} / \mathrm{CH}_{3} \mathrm{NO}_{2}$-catalyst reactant proportions were: acid $(2 \mathrm{mmol}), \mathrm{AlCl}_{3}(10 \mathrm{mmol})$ in $\mathrm{CH}_{3} \mathrm{NO}_{2}(80 \mathrm{mmol})$, solvent $(10 \mathrm{~mL})$. ${ }^{C}$ Dichloromethane. DWith $\mathrm{P}_{2} \mathrm{O}_{5}$ catalyst reactant proportions were: acid $(0.5 \mathrm{~g})$ and $\mathrm{P}_{2} \mathrm{O}_{5}(5 \mathrm{~g})$ in anhydrous solvent $(10 \mathrm{~mL})$. EDichloroethane. FWith PPA catalyst reactant proportions were: $\operatorname{acid}(0.5 \mathrm{~g})$ and PPA ( $5 \mathrm{~g})$.

Initially, attempts to perform cyclization of 7 a were carried out using $\mathrm{AlCl}_{3} / \mathrm{CH}_{3} \mathrm{NO}_{2}$-catalyst for 30 min at room temperature. The product composition was examined by TLC and a flash chromatographed sample $(0.5 \mathrm{~g})$ of the cyclization reaction leading to product $8 \mathbf{a}$ was subjected to column chromatography (silica, column; $1 \times 25$ 
$\mathrm{cm}, n$-hexane/EtOAc 7:3). Unfortunately, the content of reaction product was found by GC to contain cyclic product $8 \mathrm{a}(0.12 \mathrm{~g}, 24 \%)$ and starting acid $7 \mathrm{a}(0.34 \mathrm{~g}, 70 \%)$ respectively. Attempts to improve the effectiveness of the ring closure reactions and by examining the efficacy of other catalysts to effect this cyclization process were studied. For example, cyclization of substrate $7 \mathrm{a}$ was carried out with $\mathrm{AlCl} / \mathrm{CH}_{3} \mathrm{NO}_{2}$ for longer reaction time (14h) at room temperature gave product $8 \mathrm{a}$ in $81 \%$ yield. While cyclization of $7 \mathrm{a}$ in the presence of PPAcatalyst at $190-200{ }^{\circ} \mathrm{C}$ for in $6 \mathrm{~h}$, led to an increase in yield to $73 \%$ of $8 \mathrm{a}$. When the reaction was allowed to go longer time (14h) with $\mathrm{P}_{2} \mathrm{O}_{5}$ it furnished the corresponding cyclized product $8 \mathrm{a}$ in $78 \%$ yield (entry 1 ).

Encouraged by this result, attempts were conducted to control the outcome of the cyclization of precursors 8a-f under more vigorous conditions. Out of several variations tried, the results in Table 1 and Scheme 1, illustrate the successful cyclizations that provided the polycyclic thiophenes in good yields. The formation of cyclic products were unambiguously confirmed by spectral techniques. Notably, these results exploiting the importance of electrophilic inhibition generated by a Lewis or Brønsted acid catalyst which determines the regioselectivity in Friedel-Crafts cyclizations to heterocyclic compounds. ${ }^{22}$ It seemed reasonable, therefore, that the catalyst inhibition created by coordinating of an electron-deficient species $\left(\mathrm{AlCl}_{3}\right.$ or proton) of the catalyst on heteroatoms in substrate, would decrease the rate of ring closures of heteroarenes 7a-f under normal conditions. This suggested that the rate of the cyclization process strongly depends on the strength of Lewis or Brønsted catalysts. Thus, we deduced that the poor catalysts are unable to coordinate effectively with the heteroatoms present in the substrate. Consequently, the mild catalysts mentioned are suitable for optimization of cyclization reactions in order to bring about ring closure completely. Cyclization processes could be achieved by optimizing the reaction conditions using more than a stoichiometric of such mild catalyst, high temperatures and long reaction times.

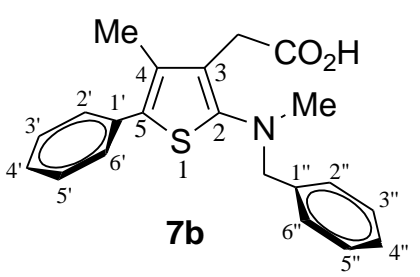

2-(2-(N-benzyl- $N$-methylamino)-4methyl-5-phenylthiophen-3-yl)acetic acid

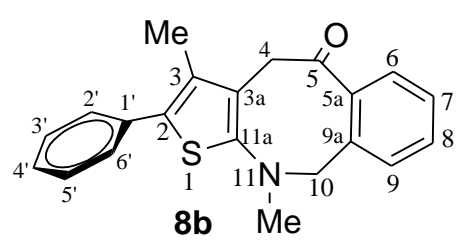

4,5,10-Trihydro-3,11-dimethyl-2-phenylbenzo[f]thieno[2,3-b]azocin-5 (11H)-one

Figure 2. Structures of tricyclic thiophene $\mathbf{8 b}$ and its precursor acid $\mathbf{7 b}$.

A plausible mechanism ${ }^{23}$ to account for transformations of heterocyclic acids 7a-f into fused tricyclic thiophenes $8 \mathrm{a}-\mathrm{f}$ is realized on the generation of acyl-carbocation ${ }^{24}$ by loss of water upon treatment of the acid precursors 7a-f with acidic catalysts. The resulting acyl-carbocation underwent ring closures to substituted tricyclic ketones in overall good yields. In the IR spectrum of 7b, absorption bands at 2612 and $1725 \mathrm{~cm}^{-1}$ attributed to the $\mathrm{O}-\mathrm{H}$ and carbonyl stretching frequencies, respectively. The ${ }^{1} \mathrm{H}$ NMR spectrum of $7 \mathbf{b}$ exhibited five singlet signals at 2.33, 2.92, 3.87, 4.60 and 10.45 ppm, respectively, related to $\mathrm{CH}_{3}, \mathrm{~N}-\mathrm{CH}_{3}, \mathrm{C} \alpha \mathrm{H}_{2}, \mathrm{Ph}-\mathrm{CH}_{2}$ and $\mathrm{COOH}$ groups, while ten aromatic protons appeared at an average of $\delta 7.08-7.37$ ppm with multiplicity of different values of coupling constants. On the other hand, the structure of cyclic product $\mathbf{8 b}$ was deduced from NMR spectroscopic data, as described for $7 \mathbf{b}$ as a representative example (Fig. 2). The ${ }^{1} \mathrm{H}$ NMR spectra for tricyclic 9a displayed several distinct signals for four groups as $\mathrm{CH}_{3}$ at $2.33 \mathrm{ppm}, \mathrm{N}-\mathrm{CH}_{3}$ at $3.10 \mathrm{ppm}, \mathrm{C}^{4} \mathrm{H}_{2}$ at $3.67 \mathrm{ppm}$ and $\mathrm{C}^{10} \mathrm{H}_{2}$ at $4.53 \mathrm{ppm}$. Meanwhile, aromatic protons appeared in the rang of 7.08-7.85 ppm, which showed the inner signals overlapping. 
In this context, it is worth mentioning that despite more than 130 years of history, the Friedel-Crafts reactions promoted by Brønsted and Lewis acids are still in the forefront of organic synthesis and become one of the most commonly used methodologies for the construction of carbo-and heterocyclic compounds. Nowadays, the Friedel-Crafts processes constitute an essential synthetic step in a wide number of industry processes regarding to the production of natural products and biologically active drug skeletons (Fig. 3 ). ${ }^{25-30}$

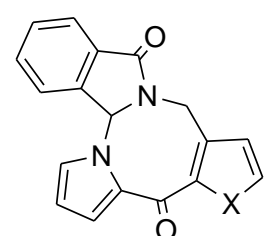

$\mathbf{a}: \mathrm{X}=\mathrm{S} ; \mathbf{b}: \mathrm{X}=\mathrm{CH}=\mathrm{CH}$

Benzodiazocines

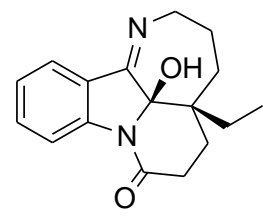

Mersicarpine (Hydropyrido[1,2-a]indole)

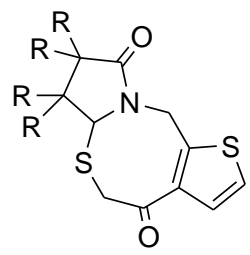

a: $\mathrm{R}=\mathrm{H} ; \mathbf{b}: \mathrm{R}=\mathrm{Me}$

Pyrrolothienothiazocines

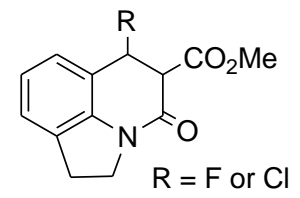

(Pyrido[1,2-a]indolones)

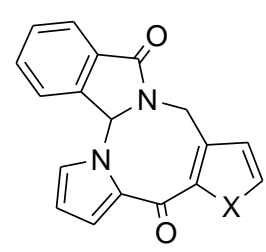

a: $\mathrm{X}=\mathrm{S} ; \mathbf{b}: \mathrm{X}=\mathrm{CH}=\mathrm{CH}$

Benzodiazocines

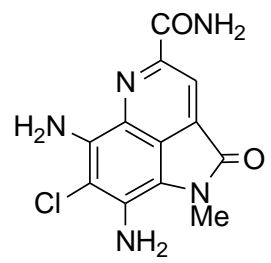

Ammosamide $\mathrm{B}$ (Pyrroloquinoline )

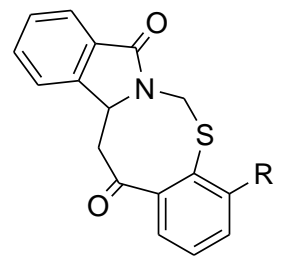

a: $\mathrm{R}=\mathrm{H}$; $\mathbf{b}: \mathrm{R}=\mathrm{Br} ; \mathbf{c}: \mathrm{R}=\mathrm{OMe}$

Tetracyclic thiazocines

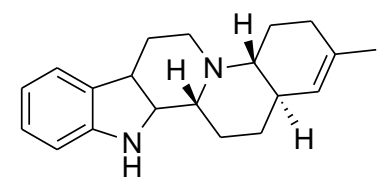

Tangutorina (Indolizinoindolone)

Figure 3. Some of condensed heterocyclic skeletons synthesized by Friedel-Crafts processes.

The scope, limitation and the great versatility of inter-and intramolecular Friedel-Crafts acylation and alkylation reactions are expanding rapidly and the actual contribution of classic and asymmetric Friedel-Crafts approaches on aromatics (benzene and more electron rich aromatics) as well as electron-rich heteroaromatics (thiophene, indole, quinoline) constitutes the major area of synthetic community. In doing this, many comprehensive reviews and books are leaving more detailed descriptions of applications, orientations, mechanisms and outcomes of Friedel-Crafts reactions concerning synthesis and functionalization of polycyclic systems are described. ${ }^{31-36}$ As reported, ${ }^{37}$ Friedel-Crafts reactions are macrocyclization strategies featured by small enthalpic and relatively large entropic barriers in the transition state. Apart from elimination of transannular interactions, Baeyer and Pitzer strains are also involved in dealing with medium-ring compounds formation. To overcome of these disappointingly impediments encountered in ring closure step, cyclizations could carried out under more drastic conditions catalyzed by mild catalyst-type which would allow ring closing process to occur.

\section{Conclusions}

We have developed expedient and efficient procedures for the constructions of fused tricyclic thiophenes via intramolecular Friedel-Crafts cycliacylations. This protocol allows easy access to functionalized thiophene fused with medium sized $\mathrm{N}$-heterocyclic ring systems (e.g. benzo-and pyrido fused thieno[2,3-b]azepinones, thieno[2,3-b]azocinones and thieno[2,3-b]azoninones) in good yields by ring closures of heterocyclic carboxylic 
acids 7a-f. The ease of workup and wide variability of the method, simplifies the construction of condensed thiophene-based scaffolds of sound promising pharmaceutical applicability.

\section{Experimental Section}

General. Commercially available reagents were used without further purification unless otherwise stated; solvents were dried by standard procedures. Melting points were measured by a digital Gallenkamp capillary melting point apparatus and are uncorrected. IR spectra were determined on a Shimadzu 470 Infrared spectrophotometer using $\mathrm{KBr}$ wafer technique $\left(v \mathrm{~cm}^{-1}\right)$. The ${ }^{1} \mathrm{H}$ NMR and ${ }^{13} \mathrm{C} N M R$ spectra were recorded on JEOL LA $400 \mathrm{MHz}$ FT-NMR (400 MHz for ${ }^{1} \mathrm{H}$ NMR, $100 \mathrm{MHz}$ for ${ }^{13} \mathrm{C} \mathrm{NMR}$ ) and on a Varian $\mathrm{NMR}$ (90 MHz) spectrometers using $\mathrm{CDCl}_{3}$ solvent with TMS as internal standard. Chemical shifts are given in parts per million $(\delta)$, and the coupling constants $(J)$ are given in Hertz. Mass spectra were performed by JEOL JMS 600 spectrometer at under electron impact at $70 \mathrm{eV}$. Elemental analyses were performed using a $\mathrm{GmbH} \mathrm{Vario} \mathrm{EL}$ III, 2400, CHNS-elemental analyzer and halogens were determined manually at microanalytical unit. The reaction progress monitoring was accomplished by thin layer chromatography (TLC; silica-gel 60 F254 plates, $n$-hexane/ethyl acetate) and plates were visualized by UV light (at 254 and/or 360 nm). Flash column chromatography was prepared from Aldrich silica gel, 70-230 mesh. Substituted ethyl 2-aminothiophene-3carboxylate 1 used in this work was obtained as yellow crystals $\left(88 \%\right.$ yield), mp $98-99{ }^{\circ} \mathrm{C}$ (Lit. ${ }^{20} \mathrm{mp} 94-96^{\circ} \mathrm{C}$ ) by heating a mixture of ethyl cyanoacetate, sulfur, phenyl acetone and diethyl amine in ethanol for 10 hours .

3-(Chloromethyl)-4-methyl-5-phenylthiophen-2-amine (3). This intermediate compound was obtained in two reaction steps starting with ethyl 2-amino-4-methyl-5-phenylthiophene-3-carboxylate (1). A summary of the steps is given in the following:

(i) A solution of the ester 1 (3.9 g, $15 \mathrm{mmol})$ in dry THF $(20 \mathrm{~mL})$ was added dropwise over 20 min to an ice-cold suspension of $\mathrm{LiAlH}_{4}(0.9 \mathrm{~g}, 25 \mathrm{mmol})$ in THF $(40 \mathrm{~mL})$ and the reaction was stirred for $2 \mathrm{~h}$ at $0-5{ }^{\circ} \mathrm{C}$. The reaction mixture was refluxed for $4 \mathrm{~h}$, cooled to $0^{\circ} \mathrm{C}$ and then quenched by dropwise addition and stirring of water $(5 \mathrm{~mL})$ followed by $\mathrm{NaOH}$ solution $(25 \mathrm{~mL}, 20 \%)$. The resulting mixture was filtered and the filtrate was basified with $\mathrm{NaOH}(2 \mathrm{M})$ until pH 10, then it was extracted with EtOAc $(3 \times 40 \mathrm{~mL})$. The combined organic layer was washed, dried over $\mathrm{Na}_{2} \mathrm{SO}_{4}$, filtered and the solvent was evaporated in vacuo to afford the crude alcohol. Crystallization from ethanol gave $(2.7 \mathrm{~g}, 84 \%)$ of pure (2-amino-4-methyl-5-phenylthiophen-3-yl)methanol (2) as yellow crystals, $\mathrm{mp} 126-129^{\circ} \mathrm{C}$; IR (KBr) $v_{\max } 3434,3390,3080,2960,1590,1470,1445,1330 \mathrm{~cm}^{-1} ;{ }^{1} \mathrm{H} \mathrm{NMR}$ $\left(400 \mathrm{MHz}, \mathrm{CDCl}_{3}, \delta, \mathrm{ppm}\right): 2.37\left(3 \mathrm{H}, \mathrm{s}, \mathrm{CH}_{3}\right), 4.61\left(2 \mathrm{H}, \mathrm{s}, \mathrm{CH}_{2} \mathrm{O}\right), 7.10(1 \mathrm{H}, \mathrm{tdd}, J$ 7.7, 1.9, $1.6 \mathrm{~Hz}), 7.29-7.42(4 \mathrm{H}$, m, phenyl), $6.25\left(2 \mathrm{H}, \mathrm{s}, \mathrm{NH}_{2}\right) ;{ }^{13} \mathrm{C} \mathrm{NMR}\left(100 \mathrm{MHz}, \mathrm{CDCl}_{3}, \delta, \mathrm{ppm}\right): 58.4\left(1 \mathrm{C},-\mathrm{CH}_{3}\right), 64.7\left(1 \mathrm{C},-\mathrm{CH}_{2}\right), 127.1(2 \mathrm{C}, \mathrm{Ar}$, C-2', C-6'), 128.9 (1C, Ar., C-4'), 129.0 (2C, Ar., C-3', C-5'), 129.2 (1C, Ar., C-1'), 133.0 (1C, Ar., C-3), 133.1 (1C, Ar., C-4), 137.5 (1C, Ar., C-5), 163.0 (1C, Ar., C-2). Anal. Calcd. for $\mathrm{C}_{12} \mathrm{H}_{13} \mathrm{NOS}$ (219); C, 65.75; H, 5.93; N, 6.39; S, 14.61. Found; C, 65.90; H, 5.84; N, 6.44; S, 14.50\%.

(ii) To a solution of alcohol $2(3.5 \mathrm{~g}, 16 \mathrm{mmol})$ in dry diethyl ether $(30 \mathrm{~mL})$ was added $\mathrm{SOCl}_{2}(4.8 \mathrm{~g}, 40 \mathrm{mmol})$ and the reaction was refluxed on a water bath for $2 \mathrm{~h}$. The reaction mixture was then poured with efficient stirring into cold water $(70 \mathrm{~mL})$ and extracted with ether $(3 \times 40 \mathrm{~mL})$. The combined organic layers were washed with $\mathrm{NaHCO}_{3}$ solution $(20 \mathrm{~mL}, 30 \%)$, washed with water and dried over anhydrous $\mathrm{MgSO}_{4}$. Filtration and the solvent removed in vacuo to afford (3.4 g, 90\%) of 3-(chloromethyl)-4-methyl-5-phenylthiophen-2-amine (3) as brown solid $\mathrm{mp} 85-8{ }^{\circ} \mathrm{C}$, which was used without further purification. IR (KBr) $v_{\max } 3410,3347,3050,3062$, 2970, 1585, 1470, $1380 \mathrm{~cm}^{-1} ;{ }^{1} \mathrm{H}$ NMR $\left(90 \mathrm{MHz} \mathrm{CDCl}_{3}, \delta, \mathrm{ppm}\right): 2.4\left(3 \mathrm{H}, \mathrm{s}, \mathrm{CH}_{3}\right), 4.8\left(2 \mathrm{H}, \mathrm{s}, \mathrm{CH}_{2} \mathrm{Cl}\right), 6.60(2 \mathrm{H}, \mathrm{s}$, 
$\mathrm{NH}_{2}$ ), 6.5-7.9 (5H, m, phenyl). Anal. Calcd. for $\mathrm{C}_{12} \mathrm{H}_{13} \mathrm{CINOS}$ (237.5); C, 60.63; $\mathrm{H}, 5.05 ; \mathrm{Cl}, 14.94 ; \mathrm{N}, 5.89 ; \mathrm{S}$, 13.47. Found; C, 60.90; $\mathrm{H}, 5.16 ; \mathrm{Cl}, 14.80 ; \mathrm{N}, 5.85 ; \mathrm{S}, 13.29 \%$.

Substituted thiophene alkanoic acids $(5 \mathbf{a}, \mathbf{b})$. These acids were synthesized via two different pathways (path a and path $b$ ) starting from chloride 3. A summary of the steps is given in the following:

Path A. Synthesis of 2-(2-amino-4-methyl-5-phenylthiophen-3-yl)acetic acid (5a) starting from chloride $\mathbf{3}$ via two reaction steps.

(i) A mixture of chloride $3(3.3 \mathrm{~g}, 14 \mathrm{mmol})$ and $\mathrm{KCN}(2.6 \mathrm{~g}, 40 \mathrm{mmol})$ in ethanol $(25 \mathrm{~mL})$ was refluxed for $6 \mathrm{~h}$. Afterwards, the excess solvent was removed in vacuo and the residue was diluted with water $(50 \mathrm{~mL})$. The product was extracted with ether $(3 \times 30 \mathrm{~mL})$ and the combined ether extracts washed with water, dried and concentrated in vacuo to yield the crude cyanide. Crystallization from benzene gave (2.5 g, 80\%) of pure 2-(2amino-4-methyl-5-phenylthiophen-3-yl)acetonitrile (4) as white needles; mp 90-92 ${ }^{\circ} \mathrm{C}$; IR (KBr) $V_{\max } 3430$, 3370, 3033, 2950, 2248, 1590, 1490, 1365, $1283 \mathrm{~cm}^{-1} ;{ }^{1} \mathrm{H}$ NMR $\left(90 \mathrm{MHz}, \mathrm{CDCl}_{3}, \delta, \mathrm{ppm}\right): 2.3\left(3 \mathrm{H}, \mathrm{s}, \mathrm{CH}_{3}\right), 4.2$ $\left(2 \mathrm{H}, \mathrm{s}, \mathrm{CH}_{2} \mathrm{CN}\right), 6.2\left(2 \mathrm{H}, \mathrm{s}, \mathrm{NH}_{2}\right), 6.7-8.0\left(5 \mathrm{H}, \mathrm{m}\right.$, phenyl). Anal. Calcd. for $\mathrm{C}_{13} \mathrm{H}_{12} \mathrm{~N}_{2} \mathrm{~S}(228) ; \mathrm{C}, 68.42 ; \mathrm{H}, 5.26 ; \mathrm{N}$, 12.28; S, 14.03. Found; C, 68.47; $H, 5.24 ; \mathrm{N}, 12.41 ; \mathrm{S}, 13.84 \%$.

(ii) A mixture of nitrile 4 (4.5 g, $20 \mathrm{mmol}), \mathrm{NaOH}(3.2 \mathrm{~g}, 80 \mathrm{mmol})$, in ethanol $(30 \mathrm{~mL})$ was refluxed for $10 \mathrm{~h}$. The reaction was concentrated to dryness and the residue was dissolved in water $(20 \mathrm{~mL})$, neutralized by addition of $\mathrm{AcOH}(10 \%)$ until $\mathrm{pH} 6-7$, and finally it was extracted with AcOEt $(3 \times 40 \mathrm{~mL})$. The combined extract was separated, washed with water, dried, and the solvent was evaporated in vacuo to give of crude product. Crystallization from benzene gave (3.9 g, 82\%) of pure 2-(2-amino-4-methyl-5-phenylthiophen-3-yl)acetic acid

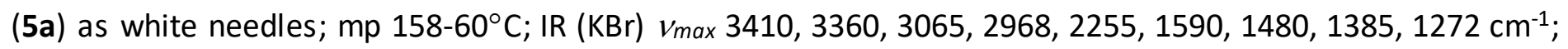
${ }^{1} \mathrm{H}$ NMR $\left(400 \mathrm{MHz}_{\mathrm{CDCl}}, \delta, \mathrm{ppm}\right): 2.36\left(3 \mathrm{H}, \mathrm{s}, \mathrm{CH}_{3}\right), 3.88\left(2 \mathrm{H}, \mathrm{s}, \mathrm{C} \alpha \mathrm{H}_{2}\right), 5.91\left(2 \mathrm{H}, \mathrm{s}, \mathrm{NH}_{2}\right), 7.10(1 \mathrm{H}, \mathrm{tdd}, J$ 7.7, 1.9, $1.6 \mathrm{~Hz}), 7.29-7.42\left(4 \mathrm{H}, \mathrm{m}\right.$, phenyl), $9.60(1 \mathrm{H}, \mathrm{s}, \mathrm{COOH}) ;{ }^{13} \mathrm{C} \mathrm{NMR}\left(100 \mathrm{MHz}, \mathrm{CDCl}_{3}, \delta, \mathrm{ppm}\right): 14.2\left(1 \mathrm{C},-\mathrm{CH}_{3}\right)$, 32.6 (1C, $-\mathrm{CH}_{2}$ ), 127.1 (2C, Ar., C-2', C-6'), 128.9 (1C, Ar., C-4'), 129.0 (2C, Ar., C-3', C-5'), 132.1 (1C, Ar., C-1'), 133.0 (1C, Ar., C-3), 133.1 (1C, Ar., C-4), 137.5 (1C, Ar., C-5), 163.0 (1C, Ar., C-2), 174.0 (1C, -COOH). Anal. Calcd. for $\mathrm{C}_{13} \mathrm{H}_{13} \mathrm{NO}_{2} \mathrm{~S}$ (247); C, 63.15; H, 5.26; N, 5.66; S, 12.95. Found; C, 63.09; H, 5.33; N, 5.49; S, $13.08 \%$.

Path B. 3-(2-Amino-4-methyl-5-phenylthiophen-3-yl)propanoic acid (5b). A solution of chloride 3 (3.5 g, 15 $\mathrm{mmol})$ in dry benzene $(20 \mathrm{~mL})$ was added dropwise over $10 \mathrm{~min}$ to an ice-cold suspension of sodio-malonic ester prepared from $\mathrm{Na}(0.8 \mathrm{~g}$. atom, $35 \mathrm{mmol})$ and diethyl malonate $(4.8 \mathrm{~g}, 30 \mathrm{mmol})$ in absolute ethanol (30 $\mathrm{mL}$ ). After complete addition, the reaction mixture was refluxed for $6 \mathrm{~h}$ and the solvent was removed in vacuo. The residue was then refluxed for $1 \mathrm{~h}$ with $\mathrm{KOH}$ solution $(20 \mathrm{~mL}, 30 \%)$. The reaction mixture was cooled and acidified with $\mathrm{HCl}$ solution $(40 \mathrm{~mL}, 30 \%)$. The precipitate was filtered, washed with water and dried. This resulted dibasic acid was heated at $170-180^{\circ} \mathrm{C}$ on an oil bath with stirring for 10 min and the melted residue was poured into acetone $(40 \mathrm{~mL})$. To the acetone solution was added charcoal $(0.5 \mathrm{~g})$, warmed, filtered and the solvent was evaporated in vacuo to give the crude acid. Crystallization from acetone gave $(2.8 \mathrm{~g}, 75 \%)$ of pure aminoacid $\mathbf{5 b}$ as pale yellow crystals, $\mathrm{mp} 144-147{ }^{\circ} \mathrm{C}$ (acetone); IR (KBr) $v_{\max } 3410,3370,3045,2955$, 2540, 1730, 1600, 1590, 1460, 1445, $1335 \mathrm{~cm}^{-1} ;{ }^{1} \mathrm{H}$ NMR (400 MHz, CDCl $\left., \delta, \mathrm{ppm}\right): 2.33\left(3 \mathrm{H}, \mathrm{s}, \mathrm{CH}_{3}\right), 2.62(2 \mathrm{H}$, t, J $\left.7.4 \mathrm{~Hz}, \mathrm{C} \beta \mathrm{H}_{2}\right), 2.94\left(2 \mathrm{H}, \mathrm{t}, J 7.4 \mathrm{~Hz}, \mathrm{C} \alpha \mathrm{H}_{2}\right), 6.55\left(2 \mathrm{H}, \mathrm{s}, \mathrm{NH}_{2}\right), 7.10(1 \mathrm{H}, \mathrm{tdd}, J$ 7.7, 1.9, $1.6 \mathrm{~Hz}), 7.29-7.42(4 \mathrm{H}$, m, phenyl), $10.38(1 \mathrm{H}, \mathrm{s}, \mathrm{COOH}) ;{ }^{13} \mathrm{C} \mathrm{NMR}\left(100 \mathrm{MHz}, \mathrm{CDCl}_{3}, \delta, \mathrm{ppm}\right): 14.2\left(1 \mathrm{C},-\mathrm{CH}_{3}\right), 30.0\left(1 \mathrm{C},-\mathrm{C} \mathrm{H}_{2}\right), 34.2(1 \mathrm{C}$, - $\mathrm{C} \alpha \mathrm{H}_{2}$ ), 127.1 (2C, Ar., C-2', C-6'), 128.9 (1C, Ar., C-4'), 129.0 (2C, Ar., C-3', C-5'), 132.1 (1C, Ar., C-1'), 133.0 (1C, Ar., C-3), 133.1 (1C, Ar., C-4), 137.5 (1C, Ar., C-5), 163.0 (1C, Ar., C-2), 177.7 (1C, -COOH). Anal. Calcd. for $\mathrm{C}_{14} \mathrm{H}_{15} \mathrm{NO}_{2} \mathrm{~S}(261) ; \mathrm{C}, 64.36 ; \mathrm{H}, 5.74 ; \mathrm{N}, 5.36 ; \mathrm{S}, 12.26$. Found; C, 64.44; H, 5.80; N, 5.48; S, 12.14\%. 
General procedure for the synthesis of bromo-alkanoic acid $(6 \mathbf{6}, \mathbf{b})$. To a suspension of acid $\mathbf{5 a}$ or $\mathbf{5 b}$ (15 $\mathrm{mmol})$ in water $(20 \mathrm{~mL})$ was added concentrated $\mathrm{HCl}(15 \mathrm{~mL})$ and the whole mixture was warmed on a water bath until solids was dissolved. The solution was cooled in an ice bath and a solution of $\mathrm{NaNO}_{2}(1.4 \mathrm{~g}, 20$ $\mathrm{mmol})$ in water $(15 \mathrm{~mL})$ was added slowly with stirring. The resulting solution was stirred for 10 min while a solution of $\mathrm{KBr}(3.0 \mathrm{~g}, 25 \mathrm{mmol})$ in water $(15 \mathrm{~mL})$ was added with occasional shaking. The reaction was then heated on water bath for $1 \mathrm{~h}$. The reaction mixture was cooled to room temperature and the resulting precipitate was filtered, washed with water and dried to give the crude product. Purifications, yields and spectral data are given in the following:

2-(2-Bromo-4-methyl-5-phenylthiophen-3-yl)acetic acid (6a). Light brown solid; 74\%, mp 180-83 으 (AcOEt); IR $(\mathrm{KBr}) V_{\max } 3020,2943,2640,1723,1600,1580,1470,1440,1375 \mathrm{~cm}^{-1} ;{ }^{1} \mathrm{H}$ NMR $(400 \mathrm{MHz}, \mathrm{CDCl} 3, \mathrm{ppm}), \delta$ $2.41\left(3 \mathrm{H}, \mathrm{s}, \mathrm{CH}_{3}\right), 3.90\left(2 \mathrm{H}, \mathrm{s}, \mathrm{CH}_{2}\right), 7.27-7.48\left(5 \mathrm{H}, \mathrm{m}\right.$, phenyl ), $10.42(1 \mathrm{H}, \mathrm{s}, \mathrm{COOH}) ;{ }^{13} \mathrm{C} \mathrm{NMR}\left(100 \mathrm{MHz} \mathrm{CDCl}_{3}\right.$,

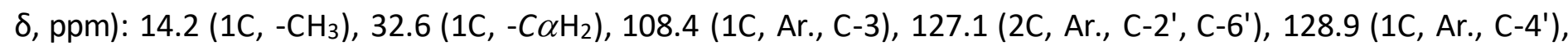
129.0 (2C, Ar., C-3', C-5'), 129.2 (1C, Ar., C-1'), 133.0 (1C, Ar., C-4), 133.1 (1C, Ar., C-5), 137.5 (1C, Ar., C-2), 174.0 (1C, $-\mathrm{COOH}$ ). Anal. Calcd. for $\mathrm{C}_{13} \mathrm{H}_{11} \mathrm{BrO}_{2} \mathrm{~S}(311) ; \mathrm{C}, 50.16 ; \mathrm{H}, 3.53 ; \mathrm{Br}, 25.72 ; \mathrm{S}, 10.28$. Found; $\mathrm{C}, 50.30 ; \mathrm{H}$, 3.62; $\mathrm{Br}, 25.78 ; \mathrm{S}, 10.02 \%$.

3-(2-Bromo-4-methyl-5-phenylthiophen-3-yl)propanoic acid (6b). Yellow crystals; 70\%, mp 154-56 ㅇ (AcOEt); IR (KBr) $v_{\max } 3030,2955,2580,1720,1590,1468,1445,1377 \mathrm{~cm}^{-1} ;{ }^{1} \mathrm{H} \mathrm{NMR}\left(400 \mathrm{MHz}, \mathrm{CDCl}_{3}, \mathrm{ppm}\right), \delta 2.39(3 \mathrm{H}$, $\left.\mathrm{s}, \mathrm{CH}_{3}\right), 2.65\left(2 \mathrm{H}, \mathrm{t}, J 7.4 \mathrm{~Hz}, \mathrm{CBH}_{2}\right), 3.15\left(2 \mathrm{H}, \mathrm{t}, J 7.4 \mathrm{~Hz}, \mathrm{C} \alpha \mathrm{H}_{2}\right), 7.27-7.48(5 \mathrm{H}, \mathrm{m}$, phenyl), $10.91(1 \mathrm{H}, \mathrm{s}, \mathrm{COOH})$; ${ }^{13} \mathrm{C}$ NMR (100 MHz, CDCl $\left.3, \delta, \mathrm{ppm}\right): 14.2\left(1 \mathrm{C},-\mathrm{CH}_{3}\right), 30.0\left(1 \mathrm{C},-{\mathrm{C} \beta \mathrm{H}_{2}}_{2}\right), 34.0\left(1 \mathrm{C},-\mathrm{C} \alpha \mathrm{H}_{2}\right), 108.4(1 \mathrm{C}, \mathrm{Ar} ., \mathrm{C}-3)$, 127.1 (2C, Ar., C-2', C-6'), 128.9 (1C, Ar., C-4'), 129.00 (2C, Ar., C-3', C-5'), 129.2 (1C, Ar., C-1'), 133.0 (1C, Ar., C4), 133.1 (1C, Ar., C-5), 137.5 (1C, Ar., C-2), 177.7 (1C, -COOH). Anal. Calcd. for $\mathrm{C}_{14} \mathrm{H}_{13} \mathrm{BrO}_{2} \mathrm{~S}(325) ; \mathrm{C}, 51.69 ; \mathrm{H}$, 4.00; $\mathrm{Br}, 24.61 ; \mathrm{S}, 9.84$. Found; C, 51.91; H, 3.85; Br, 24.90; S, 9.77\%.

General procedure for arylation of bromo-thiophene carboxylic acids (6a,b). A mixture of carboxylic acids $6 a$ or $6 \mathbf{b}(10 \mathrm{mmol}), \mathrm{K}_{2} \mathrm{CO}_{3}(2.7 \mathrm{~g}, 20 \mathrm{mmol})$, amine; $\mathrm{PhNHMe}$ or $\mathrm{PhCH}_{2} \mathrm{NHMe}$ or 2-picolylmethylamine (14 mmol) and $\mathrm{CuCl}(0.3 \mathrm{~g})$ in DMF $(20 \mathrm{~mL})$ was heated with efficient stirring for $10 \mathrm{~h}$ at $120-130{ }^{\circ} \mathrm{C}$. The progress of the reaction was monitored by TLC (hexane:ACOEt; 8:2). After the completion of the reaction, the reaction mixture was decomposed with aqueous $\mathrm{NaOH}$ solution $(100 \mathrm{~mL}, 10 \%)$. Afterwards, decolorizing carbon $(2 \mathrm{~g})$ was added and the mixture was heated for $10 \mathrm{~min}$ and filtered on hot. The cold filtrate was acidified with aqueous $\mathrm{HCl}$ solution ( $40 \mathrm{~mL}, 20 \%$ ) and the formed precipitate was filtered, washed and dried to give the crude acids 7a-f. The crude acids were purified by flash chromatography (basic alumina, EtOAc/n-hexane, 1/1). Further purifications, yields and spectral data of acids 7a-f are given in the following:

2-(2-(N-Methyl-N-phenylamino)-4-methyl-5-phenylthiophen-3-yl)acetic acid (7b). Colourless crystals; 72\%, $\mathrm{mp} 141-43$ oC (AcOEt); IR (KBr) $v_{\max } 3035,2950,2564,1720,1580,1440,1382,1277 \mathrm{~cm}^{-1} ;{ }^{1} \mathrm{H} \mathrm{NMR}(400 \mathrm{MHz}$, $\left.\mathrm{CDCl}_{3}, \mathrm{ppm}\right), \delta 2.32\left(3 \mathrm{H}, \mathrm{s}, \mathrm{CH}_{3}\right), 3.15\left(3 \mathrm{H}, \mathrm{s}, \mathrm{N}-\mathrm{CH}_{3}\right), 3.90\left(2 \mathrm{H}, \mathrm{s}, \mathrm{C} \alpha \mathrm{H}_{2}\right), 6.89(1 \mathrm{H}, \mathrm{tt}, J 8.1,1.2 \mathrm{~Hz}), 7.08(2 \mathrm{H}$, $\mathrm{dtd}, J$ 8.2, 1.2, $0.5 \mathrm{~Hz}), 7.13(1 \mathrm{H}, \mathrm{tdd}, J 7.7,2.0,1.6 \mathrm{~Hz}), 7.27(2 \mathrm{H}, \mathrm{dddd}, J$ 8.2, 8.1, 1.4, $0.5 \mathrm{~Hz}), 7.34(2 \mathrm{H}, \mathrm{dddd}, J$ 7.9, 7.7, 1.3, $0.6 \mathrm{~Hz}), 7.47(2 \mathrm{H}$, dddd, J 7.9, 1.9, 1.6, $0.5 \mathrm{~Hz}), 11.14(1 \mathrm{H}, \mathrm{s}, \mathrm{COOH}) ;{ }^{13} \mathrm{C} \mathrm{NMR}(100 \mathrm{MHz}, \mathrm{CDCl}, \delta$,

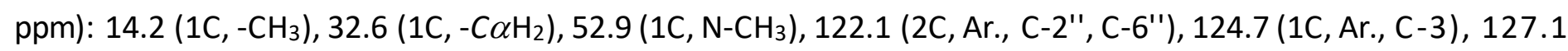
(2C, Ar., C-2', C-6'), 128.9 (1C, Ar., C-4'), 129.0 (2C, Ar., C-3', C-5'), 129.2 (2C, Ar., C-3'', C-5''), 132.1 (1C, Ar., C4"), 133.0 (1C, Ar., C-1'), 133.1 (1C, Ar., C-4), 137.5 (1C, Ar., C-5), 140.1 (1C, Ar., C-2), 144.7 (1C, Ar., C-1"), 174.0 (1C, -COOH); MS (El, $70 \mathrm{eV}) \mathrm{m} / z(\%), 338\left(\mathrm{M}^{+}+1,52\right), 337$ (M+, 34), 292 (100), 278 (62), 200 (45), 172 (92), 106 (20), 77 (18). Anal. Calcd. for $\mathrm{C}_{20} \mathrm{H}_{19} \mathrm{NO}_{2} \mathrm{~S}$ (337); C, 71.12; H, 5.63; N, 4.15; S, 9.49. Found; C, 70.94; $\mathrm{H}$, $5.60 ; \mathrm{N}, 4.18 ; \mathrm{S}, 9.74 \%$. 
2-(2-(N-Benzyl-N-methylamino)-4-methyl-5-phenylthiophen-3-yl)acetic acid (7). Colourless plates; $74 \%, \mathrm{mp}$ $120-23$ o $\mathrm{C}(\mathrm{AcOH}) ; \mathrm{IR}(\mathrm{KBr}) V_{\max } 3070,2930,2612,1725,1590,1580,1440,1384,1248 \mathrm{~cm}^{-1} ;{ }^{1} \mathrm{H}$ NMR $(400$ $\left.\mathrm{MHz}, \mathrm{CDCl}_{3}, \mathrm{ppm}\right), \delta 2.33\left(3 \mathrm{H}, \mathrm{s}, \mathrm{CH}_{3}\right), 2.92\left(3 \mathrm{H}, \mathrm{s}, \mathrm{N}-\mathrm{CH}_{3}\right), 3.87\left(2 \mathrm{H}, \mathrm{s}, \mathrm{C} \alpha \mathrm{H}_{2}\right), 4.60\left(2 \mathrm{H}, \mathrm{s}, \mathrm{Ph}-\mathrm{CH}_{2}\right), 7.08(1 \mathrm{H}$, dddd, J 8.1, 7.9, 2.0, 1.6 Hz), 7.17-7.31 (7H, m), $7.37(2 \mathrm{H}$, dddd, J 7.9, 1.8, 1.6, $0.5 \mathrm{~Hz}), 10.45(1 \mathrm{H}, \mathrm{s}, \mathrm{COOH}) ;{ }^{13} \mathrm{C}$

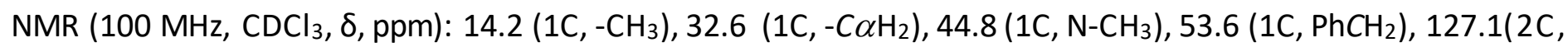
Ar., C-2"', C-6"'), 127.9 (2C, Ar., C-2', C-6'), 128.5 (2C, Ar., C-3"', C-5"'), 128.9 (2C, Ar., C-4', C-4"'), 129.0 (2C, Ar., C-3', C-5'), 132.1 (1C, Ar., C-1'), 133.0 (1C, Ar., C-3), 133.1 (1C, Ar., C-4), 136.7 (1C, Ar., C-5), 137.5 (1C, Ar., C-2), 140.1 (1C, Ar., C-1'"), 174.0 (1C, -COOH); MS (EI, 70 eV) m/z (\%), 351 (M+, 22), 306 (100), 292 (50), 263 (30), 171 (80), 105 (41), 77 (8). Anal. Calcd. for $\mathrm{C}_{21} \mathrm{H}_{21} \mathrm{NO}_{2} \mathrm{~S}$ (351); C, 71.79; $\mathrm{H}, 5.98 ; \mathrm{N}, 3.98 ; \mathrm{S}, 9.11$. Found; C, 71.64; $\mathrm{H}$, 6.19; N, 4.11; S, 8.85\%.

2-(2-(N-Methyl-N-((pyridin-2-yl)methyl)amino)-4-methyl-5-phenylthiophen-3-yl)acetic acid (7c). Yellow crystals; 77\%; mp 204 dec. 으, (AcOH); IR (KBr) $V_{\max }$ 3070, 2948, 2740, 1715, 1600, 1570, 1455, 1330, 1245 cm ${ }^{1} ;{ }^{1} \mathrm{H}$ NMR (400 MHz, CDCl $\left.3, \mathrm{ppm}\right), \delta 2.33\left(3 \mathrm{H}, \mathrm{s}, \mathrm{CH}_{3}\right), 3.02\left(3 \mathrm{H}, \mathrm{s}, \mathrm{N}-\mathrm{CH}_{3}\right), 3.87\left(2 \mathrm{H}, \mathrm{s}, \mathrm{C} \alpha \mathrm{H}_{2}\right), 4.81(2 \mathrm{H}, \mathrm{s}, \mathrm{Ph}-$ $\left.\mathrm{CH}_{2}\right), 7.09(1 \mathrm{H}$, dddd, J 8.1, 7.9, 2.0, $1.6 \mathrm{~Hz}), 7.17-7.29(4 \mathrm{H}, \mathrm{m}), 7.37(2 \mathrm{H}, \mathrm{dddd}, J 7.9,1.8,1.6,0.5 \mathrm{~Hz}), 7.63(1 \mathrm{H}$, ddd, J 7.6, 7.4, $1.9 \mathrm{~Hz}), 8.51(1 \mathrm{H}, \mathrm{ddd}, J 4.5,1.9,0.5 \mathrm{~Hz}), 10.52(1 \mathrm{H}, \mathrm{s}, \mathrm{COOH}) ;{ }^{13} \mathrm{C} \mathrm{NMR}\left(100 \mathrm{MHz}^{\mathrm{CDCl}}, \delta\right.$, ppm): $14.2\left(1 \mathrm{C},-\mathrm{CH}_{3}\right), 32.6\left(1 \mathrm{C},-\mathrm{C}_{2} \mathrm{H}_{2}\right), 44.8\left(1 \mathrm{C}, \mathrm{N}-\mathrm{CH}_{3}\right), 49.2$ (1C, pyridyl- $\left.\mathrm{CH}_{2}\right), 123.3$ (1C, Ar., C-4'), 123.5 (1C, Ar., C-4'"), 127.1 (2C, Ar., C-2', C-6'), 128.9 (1C, Ar., C-2'), 129.0 (2C, Ar., C-3', C-5'), 132.1 (1C, Ar., C-3' '), 133.0 (1C, Ar., C-1'), 133.1 (1C, Ar., C-3), 137.5 (1C, Ar., C-4), 137.7 (1C, Ar., C-5), 140.1 (1C, Ar., C-2), 149.0 (1C, Ar., C-5"), 160.1 (1C, Ar., C-1"), 174.0 (1C, -COOH); MS (EI, 70 eV) m/z (\%), $354\left(\mathrm{M}^{+}+2,9\right), 353$ (22), 337 (M+, 29), 307 (100), 292 (32), 278 (27), 201 (42), 172 (70), 106 (55), 77 (27). Anal. Calcd. for $\mathrm{C}_{20} \mathrm{H}_{20} \mathrm{~N}_{2} \mathrm{O}_{2} \mathrm{~S}$ (352); C, 68.18; $H, 5.68 ; N, 7.95 ; S, 9.09$. Found; C, 68.16; H, 5.92; N, 7.85; S, 9.27\%.

3-(2-(N-Methyl-N-phenylamino)-4-methyl-5-phenylthiophen-3-yl)propanoic acid (7d). Colourless plates; $80 \%, \mathrm{mp} 140-43$ 으 (methanol); IR (KBr) $v_{\max } 3110,2974,2642,1723,1600,1585,1440,1374,1230 \mathrm{~cm}^{-1} ;{ }^{1} \mathrm{H}$

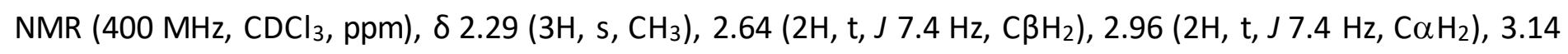
$\left(3 \mathrm{H}, \mathrm{s}, \mathrm{N}-\mathrm{CH}_{3}\right), 6.89(1 \mathrm{H}, \mathrm{tt}, J 8.1,1.2 \mathrm{~Hz}), 7.08(2 \mathrm{H}, \mathrm{dtd}, J 8.2,1.2,0.5 \mathrm{~Hz}), 7.12(\mathrm{H}, \mathrm{tdd}, J 7.7,2.0,1.6 \mathrm{~Hz}), 7.27$ $(2 \mathrm{H}$, dddd, J 8.2, 8.1, 1.4, 0.5 Hz), $7.34(2 \mathrm{H}, \mathrm{dddd}, J 7.9,7.7,1.3,0.6 \mathrm{~Hz}), 7.47(2 \mathrm{H}, \mathrm{dddd}, J 7.9,1.9,1.6,0.5 \mathrm{~Hz})$, $10.66(1 \mathrm{H}, \mathrm{s}, \mathrm{COOH}) ;{ }^{13} \mathrm{C} \mathrm{NMR}\left(100 \mathrm{MHz}, \mathrm{CDCl}_{3}, \delta, \mathrm{ppm}\right): 14.2\left(1 \mathrm{C},-\mathrm{CH}_{3}\right), 30.0\left(1 \mathrm{C},-\mathrm{C} B \mathrm{H}_{2}\right), 34.2\left(1 \mathrm{C},-\mathrm{C} \alpha \mathrm{H}_{2}\right), 52.9$ (1C, N-CH3), 122.1 (2C, Ar., C-2"', C-6'"), 124.7 (1C, Ar., C-4'), 127.1 (2C, Ar., C-2', C-6'), 128.9 (1C, Ar., C-4'), 129.0 (2C, Ar., C-3'", C-5'"), 129.2 (2C, Ar., C-3', C-5'), 132.1 (1C, Ar., C-1'), 133.0 (1C, Ar., C-3), 133.1 (1C, Ar., C4), 137.5 (1C, Ar., C-5), 140.1 (1C, Ar., C-2), 144.7 (1C, Ar., C-1'), 177.7 (1C, -COOH); MS (El, 70 eV) m/z (\%), 352 $\left(\mathrm{M}^{+}+1,18\right), 351\left(\mathrm{M}^{+}, 32\right), 306$ (100), 292 (19), 278 (48), 172 (64), 106 (25), 77 (12). Anal. Calcd. for $\mathrm{C}_{21} \mathrm{H}_{21} \mathrm{NO}_{2} \mathrm{~S}$ (351); C, 71.79; H, 5.98; N, 3.98; S, 9.11. Found; C, 71.88; H, 6.05; N, 3.90; S, 9.04\%.

3-(2-(N-Benzyl-N-methylamino)-4-methyl-5-phenylthiophen-3-yl)propanoic acid (7e). Yellow crystals; 82\%; $\mathrm{mp} 118-20$ oC (acetone); IR (KBr) $v_{\max } 3065,2970,2550,1710,1600,1590,1440,1338,1280 \mathrm{~cm}^{-1} ;{ }^{1} \mathrm{H} \mathrm{NMR}$ (400 MHz, CDCl $3, \mathrm{ppm}), \delta 2.30\left(3 \mathrm{H}, \mathrm{s}, \mathrm{CH}_{3}\right), 2.54\left(2 \mathrm{H}, \mathrm{t}, J 7.4 \mathrm{~Hz}, \mathrm{C \beta H}\right.$ ) , $2.94\left(2 \mathrm{H}, \mathrm{t}, J 7.4 \mathrm{~Hz}, \mathrm{C} \alpha \mathrm{H}_{2}\right), 2.92(3 \mathrm{H}, \mathrm{s}$, $\left.\mathrm{N}-\mathrm{CH}_{3}\right), 4.60\left(2 \mathrm{H}, \mathrm{s}, \mathrm{Ph}-\mathrm{CH}_{2}\right), 7.08(1 \mathrm{H}, \mathrm{tdd}, J$ 8.1, 2.0, $1.6 \mathrm{~Hz}), 7.17-7.31(7 \mathrm{H}, \mathrm{m}), 7.37(2 \mathrm{H}, \mathrm{dddd}, J$ 7.9, 1.8, 1.6, $0.5 \mathrm{~Hz}), 11.08(1 \mathrm{H}, \mathrm{s}, \mathrm{COOH}) ;{ }^{13} \mathrm{C} \mathrm{NMR}\left(100 \mathrm{MHz}, \mathrm{CDCl}_{3}, \delta, \mathrm{ppm}\right): 14.2\left(1 \mathrm{C},-\mathrm{CH}_{3}\right), 30.0(1 \mathrm{C},-\mathrm{CBH}), 34.2(1 \mathrm{C},-$ $\mathrm{C} \alpha \mathrm{H}_{2}$ ), 44.8 (1C, PhCH 2$), 53.6$ (1C, N-CH3), 127.1 (2C, Ar., C-2', C-6'), 127.9 (2C, Ar., C-4', C-4'), 128.5 (2C, Ar., C-2"', C-6'"), 128.9 (2C, Ar., C-3"', C-5'), 129.0 (2C, Ar., C-3', C-5'), 132.1 (1C, Ar., C-1'), 133.0 (1C, Ar., C-3), 133.1 (1C, Ar., C-4), 136.7 (1C, Ar., C-5), 137.5 (1C, Ar., C-2), 140.1 (1C, Ar., C-1"), 177.7 (1C, -COOH); MS (El, 70 eV) $m / z(\%), 365\left(\mathrm{M}^{+}, 26\right), 364\left(\mathrm{M}^{+}-1,14\right), 306$ (100), 292 (19), 277 (40), 172 (45), 105 (27), 77 (10). Anal. Calcd. for $\mathrm{C}_{22} \mathrm{H}_{23} \mathrm{NO}_{2} \mathrm{~S}$ (365); C, 72.32; H, 6.30; N, 3.83; S, 8.76. Found; C, 72.36; H, 6.44; N, 4.05; S, 8.64\%.

3-(2-(N-Methyl-N-((pyridin-2-yl)methyl)amino)-4-methyl-5-phenylthiophen-3-yl)propanoic acid (7f). Colourless crystals; 75\%; mp 185-88 ㅇ (AcOEt); IR (KBr) $v_{\max }$ 3090, 2966, 2653, 1720, 1600, 1590, 1480, 1360, 
$1289 \mathrm{~cm}^{-1} ;{ }^{1} \mathrm{H} \mathrm{NMR}\left(400 \mathrm{MHz}, \mathrm{CDCl}_{3}, \mathrm{ppm}\right), \delta 2.30\left(3 \mathrm{H}, \mathrm{s}, \mathrm{CH}_{3}\right), 2.54\left(2 \mathrm{H}, \mathrm{t}, J 7.4 \mathrm{~Hz}, \mathrm{C \beta H}_{2}\right), 2.94(2 \mathrm{H}, \mathrm{t}, J 7.4 \mathrm{~Hz}$,

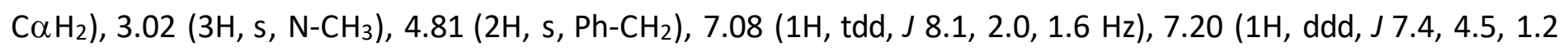
$\mathrm{Hz}), 7.23(2 \mathrm{H}, \mathrm{dddd}, J$ 8.1, 7.9, 1.4, $0.5 \mathrm{~Hz}), 7.26(1 \mathrm{H}$, ddd, J 7.6, 1.2, $0.5 \mathrm{~Hz}), 7.37$ (2H, dddd, J 7.9, 1.8, 1.6, 0.5 $\mathrm{Hz}), 7.63(1 \mathrm{H}, \mathrm{ddd}, J \mathrm{7.6}, 7.4,1.9 \mathrm{~Hz}), 8.51(1 \mathrm{H}, \mathrm{ddd}, J 4.5,1.9,0.5 \mathrm{~Hz}), 10.52(1 \mathrm{H}, \mathrm{s}, \mathrm{COOH}) ;{ }^{13} \mathrm{C} \mathrm{NMR}(100 \mathrm{MHz}$, $\left.\mathrm{CDCl}_{3}, \delta, \mathrm{ppm}\right): 14.2\left(1 \mathrm{C},-\mathrm{CH}_{3}\right), 30.0\left(1 \mathrm{C},-\mathrm{C} B H_{2}\right), 34.2\left(1 \mathrm{C},-\mathrm{C}_{2} \mathrm{H}_{2}\right), 44.8\left(1 \mathrm{C}, \mathrm{N}-\mathrm{CH}_{3}\right), 49.2(1 \mathrm{C}$, Pyridyl-CH$)$, 123.3 (1C, Ar., C-4'), 123.5 (1C, Ar., C-4'"), 127.1 (2C, Ar., C-2', C-6'), 128.9 (1C, Ar., C-2' ), 129.0 (2C, Ar., C-3', C5'), 132.1 (1C, Ar., C-3'), 133.0 (1C, Ar., C-1'), 133.1 (1C, Ar., C-3), 137.5 (1C, Ar., C-4), 137.7 (1C, Ar., C-5), 140.1 (1C, Ar., C-2), 149.0 (1C, Ar., C-5'), 160.1 (1C, Ar., C-1"), 177.7 (1C, -COOH); MS (El, 70 eV) m/z (\%), 367 (M+1, 8), 366 ( $\left.\mathrm{M}^{+}, 15\right), 365$ (31), 307 (100), 293 (39), 278 (24), 171 (35), 105 (15), 77 (8). Anal. Calcd. for $\mathrm{C}_{21} \mathrm{H}_{22} \mathrm{~N}_{2} \mathrm{O}_{2} \mathrm{~S}$ (366); C, 68.85; H, 6.01; N, 7.65; S, 8.74. Found; C, 69.04; H, 6.15; N, 7.53; S, 8.72\%.

Cycliacylations procedures. Friedel-Crafts cyclization procedures ${ }^{19}$ using $\mathrm{AlCl}_{3} / \mathrm{CH}_{3} \mathrm{NO}_{2}$ or $\mathrm{P}_{2} \mathrm{O}_{5}$ or PPA were essentially followed. The crude products were purified by flash column chromatography (basic alumina, EtOAc/n-hexane, 1/1) and by crystallization from a suitable solvents. The conditions and yields for the products 8a-f are shown in Table 1, while the physical and spectral data of the products are given in the following.

4,5-Dihydro-3,10-dimethyl-2-phenyl-benzo[f]thieno[2,3-b]azepin-5(10H)-one (8a). Yellowish crystals; 80\%; $\mathrm{mp} 168-71$ oC (acetone); IR (KBr) $v_{\max } 3070,2940,1735,1580,1480,1440,1383,1272 \mathrm{~cm}^{-1} ;{ }^{1} \mathrm{H} \mathrm{NMR}(400$ $\left.\mathrm{MHz}, \mathrm{CDCl}_{3}, \mathrm{ppm}\right), \delta 2.32\left(3 \mathrm{H}, \mathrm{s}, \mathrm{CH}_{3}\right), 3.80\left(3 \mathrm{H}, \mathrm{s}, \mathrm{N}-\mathrm{CH}_{3}\right), 3.86\left(2 \mathrm{H}, \mathrm{s}, \mathrm{C}^{4} \mathrm{H}_{2}\right), 7.11(1 \mathrm{H}, \mathrm{ddd}, J$ 8.6, 1.2, $0.6 \mathrm{~Hz})$, $7.14(1 \mathrm{H}, \mathrm{tdd}, J$ 7.7, 2.0, $1.6 \mathrm{~Hz}), 7.32(1 \mathrm{H}, \mathrm{ddd}, J$ 7.9, 7.5, $1.2 \mathrm{~Hz}), 7.34(2 \mathrm{H}, \mathrm{dddd}, J$ 7.9, 7.7, 1.3, $0.6 \mathrm{~Hz}), 7.38$ $(1 \mathrm{H}, \mathrm{ddd}, J 7.9,1.3,0.6 \mathrm{~Hz}), 7.49(2 \mathrm{H}, \mathrm{dddd}, J 7.9,1.9,1.6,0.5 \mathrm{~Hz}), 7.57(1 \mathrm{H}, \mathrm{ddd}, J 8.6,7.5,1.3 \mathrm{~Hz}) ;{ }^{13} \mathrm{C} \mathrm{NMR}$

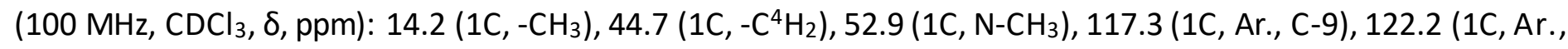
C-7), 122.5 (1C, Ar., C-5a), 126.8 (1C, Ar., C-6), 127.1 (2C, Ar., C-2', C-6'), 128.9 (1C, Ar., C-4'), 129.0 (2C, Ar., C3', C-5'), 131.7 (1C, Ar., C-8), 132.1 (1C, Ar., C-9a), 133.0 (1C, Ar., C-1'), 133.1 (1C, Ar., C-3), 137.5 (1C, Ar., C10a), 140.1 (1C, Ar., C-2), 141.6 (1C, Ar., C-3a), 199.2 (1C, C=O, C-5); MS (El, 70 eV) m/z (\%), 320 (M+1, 20), $319\left(\mathrm{M}^{+}, 40\right), 304$ (100), 291 (62), 192 (77), 170 (41), 106 (8), 77 (17). Anal. Calcd. for $\mathrm{C}_{20} \mathrm{H}_{17} \mathrm{NOS}$ (319); C, 75.23; H, 5.32; N, 4.38; S, 10.03. Found; C, 75.51; H, 5.17; N, 4.34; S, $10.14 \%$.

4,5,10-Trihydro-3,11-dimethyl-2-phenyl-benzo[f]thieno[2,3-b]azocin-5(11H)-one (8b). Colourless plates; 82\%; mp 162-65 ㅇ (methanol); IR (KBr) $V_{\max } 3053,2945,1740,1610,1590,1485,1440,1380,1240 \mathrm{~cm}^{-1} ;{ }^{1} \mathrm{H}$ NMR (400 MHz, $\left.\mathrm{CDCl}_{3}, \delta, \mathrm{ppm}\right): 2.33\left(3 \mathrm{H}, \mathrm{s}, \mathrm{CH}_{3}\right), 3.10\left(3 \mathrm{H}, \mathrm{s}, \mathrm{N}-\mathrm{CH}_{3}\right), 3.67\left(2 \mathrm{H}, \mathrm{s}, \mathrm{C}^{4} \mathrm{H}_{2}\right), 4.53\left(2 \mathrm{H}, \mathrm{s}, \mathrm{C}^{10} \mathrm{H}_{2}\right), 7.08$ $(1 \mathrm{H}, \mathrm{tdd}, J$ 8.1, 2.0, $1.6 \mathrm{~Hz}), 7.22(2 \mathrm{H}$, dddd, J 8.1, 7.9, 1.4, 0.5 Hz), $7.26(1 \mathrm{H}, \mathrm{ddd}, J$ 8.0, 1.7, $0.5 \mathrm{~Hz}), 7.36(1 \mathrm{H}$, ddd, J 7.9, 7.3, $1.7 \mathrm{~Hz}), 7.37(2 \mathrm{H}$, dddd, J 7.9, 1.8, 1.6, $0.5 \mathrm{~Hz}), 7.49(1 \mathrm{H}, \mathrm{ddd}, J$ 8.0, 7.3, $1.3 \mathrm{~Hz}), 7.85(1 \mathrm{H}, \mathrm{ddd}, J$ 7.9, 1.3, $0.5 \mathrm{~Hz}) ;{ }^{13} \mathrm{C}$ NMR $\left(100 \mathrm{MHz}, \mathrm{CDCl}_{3}, \delta, \mathrm{ppm}\right): 14.2\left(1 \mathrm{C},-\mathrm{CH}_{3}\right), 44.7\left(1 \mathrm{C},-\mathrm{C}^{4} \mathrm{H}_{2}\right), 44.8\left(1 \mathrm{C},-\mathrm{C}^{10} \mathrm{H}_{2}\right), 53.6$ (1C, N-CH3), 125.8 (1C, Ar., C-9), 126.6 (1C, Ar., C-7), 127.0 (1C, Ar., C-6), 127.1 (2C, Ar., C-2', C-6'), 128.9 (1C, Ar., C-4'), 129.0 (2C, Ar., C-3', C-5'), 131.4 (1C, Ar., C-8), 132.1 (1C, Ar., C-9a), 132.3 (1C, Ar., C-1'), 133.0 (1C, Ar., C-3), 133.1 (2C, Ar., C-5a, C-2), 137.5 (1C, Ar., C-11a), 140.1 (1C, Ar., C-3a), 199.2 (1C, C=O, C-5); MS (EI, 70 eV) $m / z(\%), 334\left(\mathrm{M}^{+}+1,19\right), 333\left(\mathrm{M}^{+}, 40\right), 318(100), 256(51), 192$ (63), 171 (74), 106 (19), 77 (11). Anal. Calcd. for $\mathrm{C}_{21} \mathrm{H}_{19} \mathrm{NOS}$ (333); C, 75.67; H, 5.70; N, 4.20; S, 9.60. Found; C, 75.52; H, 5.55; N, 4.34; S, 9.82\%.

5,6,11-Trihydro-7,10-dimethyl-8-phenyl-pyrido[3,2-f]thieno[2,3-b]azocin-5(10H)-one (8c). Pale brown

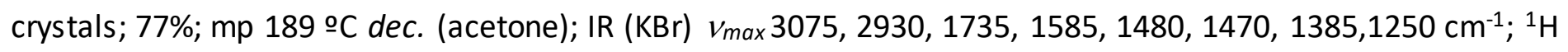
NMR (400 MHz, $\left.\mathrm{CDCl}_{3}, \delta, \mathrm{ppm}\right): 2.33\left(3 \mathrm{H}, \mathrm{s}, \mathrm{CH}_{3}\right), 3.20\left(3 \mathrm{H}, \mathrm{s}, \mathrm{N}-\mathrm{CH}_{3}\right), 3.66\left(2 \mathrm{H}, \mathrm{s}, \mathrm{C}^{6} \mathrm{H}_{2}\right), 4.91\left(2 \mathrm{H}, \mathrm{s}, \mathrm{C}^{11} \mathrm{H}_{2}\right), 7.09$ $(1 \mathrm{H}$, dddd, J 8.1, 7.9, 2.0, $1.6 \mathrm{~Hz}), 7.22(2 \mathrm{H}, \mathrm{tdd}, J 7.9,1.4,0.5 \mathrm{~Hz}), 7.25(1 \mathrm{H}, \mathrm{dd}, J 7.9,4.5 \mathrm{~Hz}), 7.37(2 \mathrm{H}, \mathrm{dddd}, J$ 7.9, 1.8, 1.6, $0.5 \mathrm{~Hz}), 7.88(1 \mathrm{H}, \mathrm{dd}, J 7.9,1.9 \mathrm{~Hz}), 8.78(1 \mathrm{H}, \mathrm{dd}, J 4.5,1.9 \mathrm{~Hz}) ;{ }^{13} \mathrm{C} \mathrm{NMR}\left(100 \mathrm{MHz}, \mathrm{CDCl}_{3}, \delta, \mathrm{ppm}\right)$ : $14.2\left(1 \mathrm{C},-\mathrm{CH}_{3}\right), 44.7\left(1 \mathrm{C},-\mathrm{C}^{6} \mathrm{H}_{2}\right), 44.8\left(1 \mathrm{C},-\mathrm{C}^{11} \mathrm{H}_{2}\right), 49.2\left(1 \mathrm{C}, \mathrm{N}-\mathrm{CH}_{3}\right), 126.7$ (1C, Ar., C-3), 127.1 (2C, Ar., C-2', 
C-6'), 128.2 (1C, Ar., C-4), 128.9 (1C, Ar., C-4'), 129.0 (2C, Ar., C-3', C-5'), 132.1 (1C, Ar., C-1'), 133.0 (1C, Ar., C4a), 133.1 (1C, Ar., C-6a), 134.7 (1C, Ar., C-9a), 137.5 (1C, Ar., C-7), 140.1 (1C, Ar., C-8), 149.0 (1C, Ar., C-2), 155.8 (1C, Ar., C-11a), 199.2 (1C, C=O, C-5); MS (El, 70 eV) m/z (\%), 334 (M+, 30), 319 (100), 304 (64), 257 (36), 190 (60), 172 (82), 106 (35), 77 (19). Anal. Calcd. for $\mathrm{C}_{20} \mathrm{H}_{18} \mathrm{~N}_{2} \mathrm{OS}$ (334); C, 71.85; H, 5.38; N, 8.38; S, 9.58. Found; C, 71.68; $\mathrm{H}, 5.50 ; \mathrm{N}, 8.15 ; \mathrm{S}, 9.74 \%$.

4,5,6-Trihydro-3,11-dimethyl-2-phenyl-benzo[g]thieno[2,3-b]azocin-6(11H)-one (8d). Pale yellow crystals; 80\%; mp 145-48 으 (acetone); IR (KBr) $v_{\max } 3070,2925,1730,1580,1475,1385,1270 \mathrm{~cm}^{-1} ;{ }^{1} \mathrm{H} \mathrm{NMR}(400 \mathrm{MHz}$, $\left.\mathrm{CDCl}_{3}, \delta, \mathrm{ppm}\right): 2.30\left(3 \mathrm{H}, \mathrm{s}, \mathrm{CH}_{3}\right), 2.83\left(2 \mathrm{H}, \mathrm{ddd}, J 17.1,7.4,1.7 \mathrm{~Hz}, \mathrm{C}^{4} \mathrm{H}_{2}\right), 3.05(2 \mathrm{H}, \mathrm{ddd}, J 15.7,7.4,1.6 \mathrm{~Hz}$, $\left.\mathrm{C}^{5} \mathrm{H}_{2}\right), 3.79\left(3 \mathrm{H}, \mathrm{s}, \mathrm{N}-\mathrm{CH}_{3}\right), 7.12(1 \mathrm{H}$, app-ddd, J 8.1, 1.2, $0.5 \mathrm{~Hz}), 7.14(1 \mathrm{H}$, app-tdd, J 7.7, 2.0, 1.6 Hz), 7.26-7.39 $(4 \mathrm{H}, \mathrm{m}), 7.48(2 \mathrm{H}$, dddd, J 7.9, 1.9, 1.6, $0.5 \mathrm{~Hz}), 7.64(1 \mathrm{H}, \mathrm{ddd}, J 8.1,7.5,1.3 \mathrm{~Hz}) ;{ }^{13} \mathrm{C} \mathrm{NMR}\left(100 \mathrm{MHz}, \mathrm{CDCl}_{3}, \delta\right.$, ppm): 14.2 (1C, $\left.-\mathrm{CH}_{3}\right), 30.0\left(1 \mathrm{C},-\mathrm{C}^{4} \mathrm{H}_{2}\right), 38.7$ (1C, $\left.-\mathrm{C}^{5} \mathrm{H}_{2}\right), 52.9\left(1 \mathrm{C}, \mathrm{N}-\mathrm{CH}_{3}\right), 117.3$ (1C, Ar., C-10), 122.2 (1C, Ar., C-8), 122.5 (1C, Ar., C-9), 126.8 (1C, Ar., C-6a), 127.1 (2C, Ar., C-2', C-6'), 128.9 (1C, Ar., C-4'), 129.0 (2C, Ar., C3', C-5'), 131.7 (1C, Ar., C-7), 132.1 (1C, Ar., C-1'), 133.0 (1C, Ar., C-3), 133.1 (1C, Ar., C-2), 137.5 (1C, Ar., C10a), 140.1 (1C, Ar., C-11a), 141.6 (1C, Ar., C-3a), 204.3 (1C, C=O, C-6); MS (El, 70 eV) m/z (\%), 335 (M+2, 10), $333\left(\mathrm{M}^{+}, 26\right), 318$ (100), 303 (43), 256 (62), 191 (20), 172 (52), 106 (30), 77 (10). Anal. Calcd. for $\mathrm{C}_{21} \mathrm{H}_{19} \mathrm{NOS}$ (333); C, 75.67; H, 5.70; N, 4.20; S, 9.60. Found; C, 75.55; H, 5.68; N, 4.42; S, 9.41\%.

4,5,6,11-Tetrahydro-3,12-dimethyl-2-phenyl-benzo[g]thieno[2,3-b]azonin-6(11H)-one (8e). Yellow plates; 78\%; mp 160-63 ㅇ (methanol); IR (KBr) $v_{\max } 3051,2948,1738,1600,1590,1470,1380,1274 \mathrm{~cm}^{-1} ;{ }^{1} \mathrm{H} \mathrm{NMR}$ (400 MHz, CDCl $3, \delta, p p m): 2.30\left(3 \mathrm{H}, \mathrm{s}, \mathrm{CH}_{3}\right), 2.92-3.08\left(7 \mathrm{H}, 2.98\left(2 \mathrm{H}\right.\right.$, app-ddd, J 16.8, 5.1, 3.0 Hz, $\left.\mathrm{C}^{4} \mathrm{H}_{2}\right), 3.01$ $\left(2 \mathrm{H}\right.$, app-ddd, J 13.1, 7.8, $\left.5.1 \mathrm{~Hz}, \mathrm{C}^{5} \mathrm{H}_{2}\right), 3.01\left(3 \mathrm{H}, \mathrm{s}, \mathrm{N}-\mathrm{CH}_{3}\right), 4.79\left(2 \mathrm{H}, \mathrm{d}, J 14.4 \mathrm{~Hz}, \mathrm{C}^{11} \mathrm{H}_{2}\right), 7.08(1 \mathrm{H}, \mathrm{tdd}, J 8.1$, 2.0, 1.6 Hz), $7.22(2 \mathrm{H}$, dddd, J 8.1, 7.9, 1.4, $0.5 \mathrm{~Hz}), 7.27(1 \mathrm{H}, \mathrm{ddd}, J 8.0,1.5,0.5 \mathrm{~Hz}), 7.37(3 \mathrm{H}, \mathrm{m}), 7.49(1 \mathrm{H}$, ddd, J 8.0, 7.5, $1.2 \mathrm{~Hz}), 7.82(1 \mathrm{H}$, ddd, J 7.9, 1.2, $0.5 \mathrm{~Hz}) ;{ }^{13} \mathrm{C} \mathrm{NMR}\left(100 \mathrm{MHz}, \mathrm{CDCl}_{3}, \delta, \mathrm{ppm}\right): 14.2\left(1 \mathrm{C},-\mathrm{CH}_{3}\right)$, $30.0\left(1 \mathrm{C},-\mathrm{C}^{4} \mathrm{H}_{2}\right), 38.7\left(1 \mathrm{C},-\mathrm{C}^{5} \mathrm{H}_{2}\right), 44.8\left(1 \mathrm{C},-\mathrm{C}^{11} \mathrm{H}_{2}\right), 53.6\left(1 \mathrm{C}, \mathrm{N}-\mathrm{CH}_{3}\right), 125.8(1 \mathrm{C}, \mathrm{Ar} ., \mathrm{C}-7), 126.6(1 \mathrm{C}, \mathrm{Ar} ., \mathrm{C}-8)$, 127.0 (1C, Ar., C-10), 127.1 (2C, Ar., C-2', C-6'), 128.9 (1C, Ar., C-4'), 129.0 (2C, Ar., C-3', C-5'), 131.4 (1C, Ar., C9), 132.1 (1C, Ar., C-1'), 132.3 (1C, Ar., C-3), 133.0 (1C, Ar., C-2), 133.1 (2C, Ar., C-3a, C-6a), 137.5 (1C, Ar., C10a), 140.1 (1C, Ar., C-11a), 206.8 (1C, C=O, C-6); MS (El, 70 eV) m/z (\%), $348\left(\mathrm{M}^{+}+1,12\right), 347$ (M+, 30), 332 (33), 317 (100), 270 (48), 190 (23), 172 (45), 106 (33), 77 (21). Anal. Calcd. for $\mathrm{C}_{22} \mathrm{H}_{21} \mathrm{NOS}$ (347); C, 76.08; H, $6.05 ; \mathrm{N}, 4.03 ; \mathrm{S}, 9.22$. Found; C, 76.00; $\mathrm{H}, 6.24 ; \mathrm{N}, 4.00 ; \mathrm{S}, 8.94 \%$.

5,6,7,12-Tetrahydro-8,11-dimethyl-9-phenyl-pyrido[3,2-g]thieno[2,3-b]azonin-5(11H)-one (8f). Yellow plates; 84\%; mp 194 ㅇ C dec. (methanol); IR (KBr) Vmax 3022, 2950, 1740, 1605, 1580, 1440, 1364, $1285 \mathrm{~cm}^{-1} ;{ }^{1} \mathrm{H}$ NMR $\left(400 \mathrm{MHz}_{\mathrm{CDCl}}, \delta, \mathrm{ppm}\right): 2.30\left(3 \mathrm{H}, \mathrm{s}, \mathrm{CH}_{3}\right), 3.01\left(2 \mathrm{H}\right.$, app-ddd, J 9.4, 7.1, $\left.6.8 \mathrm{~Hz}, \mathrm{C}^{7} \mathrm{H}_{2}\right), 3.10(2 \mathrm{H}$, appddd, J 17.1, 6.8, 1.8 Hz, C $\left.{ }^{6} \mathrm{H}_{2}\right), 3.11\left(3 \mathrm{H}, \mathrm{s}, \mathrm{N}-\mathrm{CH}_{3}\right), 4.75\left(2 \mathrm{H}, \mathrm{s}, \mathrm{C}^{12} \mathrm{H}_{2}\right), 7.08(1 \mathrm{H}, \mathrm{tdd}, J$ 8.1, 2.0, 1.6 Hz), $7.22(2 \mathrm{H}$, dddd, J 8.1, 7.9, 1.4, 0.5 Hz), $7.26(1 \mathrm{H}, \mathrm{dd}, J$ 7.9, $4.6 \mathrm{~Hz}), 7.37(2 \mathrm{H}, \mathrm{dddd}, J 7.9,1.8,1.6,0.5 \mathrm{~Hz}), 7.88(1 \mathrm{H}, \mathrm{dd}, J$ 7.9, $1.9 \mathrm{~Hz}), 8.65(1 \mathrm{H}, \mathrm{dd}, J 4.6,1.9 \mathrm{~Hz}) ;{ }^{13} \mathrm{C} \mathrm{NMR}\left(100 \mathrm{MHz}, \mathrm{CDCl}_{3}, \delta, \mathrm{ppm}\right): 14.2\left(1 \mathrm{C},-\mathrm{CH}_{3}\right), 30.0\left(1 \mathrm{C},-\mathrm{C}^{7} \mathrm{H}_{2}\right)$, $38.7\left(1 \mathrm{C},-\mathrm{C}^{6} \mathrm{H}_{2}\right), 44.8\left(1 \mathrm{C},-\mathrm{C}^{12} \mathrm{H}_{2}\right), 49.2\left(1 \mathrm{C}, \mathrm{N}-\mathrm{CH}_{3}\right), 126.7$ (1C, Ar., C-3), 127.1 (2C, Ar., C-2', C-6'), 128.2 (1C, Ar., C-4), 128.9 (1C, Ar., C-4'), 129.0 (2C, Ar., C-3', C-5'), 132.1 (1C, Ar., C-1'), 133.0 (1C, Ar., C-4a), 133.1 (1C, Ar., C-10a), 134.7 (1C, Ar., C-8), 137.5 (1C, Ar., C-9), 140.1 (1C, Ar., C-7a), 149.0 (1C, Ar., C-2), 155.8 (1C, Ar., C12a), 199.2 (1C, C=O, C-5); MS (El, $70 \mathrm{eV}) \mathrm{m} / z(\%), 350\left(\mathrm{M}^{+}+2,5\right), 348\left(\mathrm{M}^{+}, 16\right), 333$ (25), 318 (100), 271 (63), 191 (20), 172 (50), 106 (30), 77 (18). Anal. Calcd. for $\mathrm{C}_{21} \mathrm{H}_{20} \mathrm{~N}_{2} \mathrm{OS}$ (348); C, 72.41; H, 5.74; N, 8.04; S, 9.19. Found; C, 72.22; H, 5.84; N, 8.12; S, 9.35\%. 


\section{Acknowledgements}

The authors are grateful for all the facilities received during performing and preparing this work by the Chemistry department, Faculty of science Assiut University, Assiut, Egypt.

\section{References}

1. Passler, U.; Knolker, H. J. In The Alkaloids, Academic: New York, 2011; Vol. 70, p 79-147 and references therein.

https://doi.org/10.1016/B978-0-12-391426-2.00002-5

2. Xu, M.; Zhu, J.; Diao, Y.; Zhou, H.; Ren, X.; Sun, D.; Huang, J.; Han, D.; Zhao, Z.; Zhu, L.; Xu, Y.; Li, H., J. Med. Chem. 2013, 56, 7911. https://doi.org/10.1021/jm400938g

3. Wang, H. -C.; Tao, J.; Bai, W.-Y.; Xie, Z. -Y.; Li, H.; Ren, X.; Xu, Y. -X., Eur. J. Org. Chem. 2018, 1218 and references therein.

https://doi.org/10.1002/ejoc.201701663

4. Fitzner, R.; Osteritz, E. M. ; Walzer, K.; Pfeiffer, M.; Bäuerle, P., Adv. Funct. Mater., 2015, 25, 1845. https://doi.org/10.1002/adfm.201404210

5. Skotheim , T.A.; Reynolds, J.R. Eds. Handbook of Conducting Polymers 3rd Edn, CRC Press: Boca Raton, FL, USA, 2007.

6. Molvi, K. I.; Mansuri, M.; Sudarsanam, V.; Patel, M. M.; Andrabi, S. M.; Haque, N. J Enzyme Inhib Med Chem. 2008, 23, 829.

https://doi.org/10.1080/14756360701626082

7. Minetto, G.; Raveglia, L. F.; Sega, A.; Taddei, M., Eur. J. Org. Chem. 2005, 5277.

https://doi.org/10.1002/ejoc.200500387

8. Ma, L.; Yuan L.; Xu, C.; Li, G.; Tao, M.; Zhang, W., Synthesis 2013, 45, 45.

https://doi.org/10.1055/s-0032-1316821

9. Fricero, P.; Bialy, L.; Czechtizky, W.; Méndez, M.; Harrity, J. P. A., Org. Lett. 2018, 20, 198. https://doi.org/10.1021/acs.orglett.7b03558

10. Sanz-Cervera, J. F.; Blasco, R.; Piera, J.; Cynamon, M.; Ibáñez, I.; Murguía, M.; Fustero, S. J. Org. Chem., 2009, 74, 8988.

https://doi.org/10.1021/jo9016265

11. Gronowitz, S. In Thiophene and Its Derivatives, Part 1, Wiley-Interscience: New York, Gronowitz, S., Ed., 1985; pp 34-41.

12. Tünnermann, M.; Rehsies, P.; Flörke, U.; Bauer, M., Synlett 2018, 29, 2638. https://doi.org/10.1055/s-0037-1611022

13. Aurelio, L.; Flynn, B. L.; Scammells, P. J., Aust. J. Chem. 2009, 62, 402.

https://doi.org/10.1071/CH09004

14. Yu, L.-Z.; Hu, X.-B.; Xu, Q.; Shi, M. Chem. Commun. 2016, 52, 2701. https://doi.org/10.1039/C5CC09218C

15. Luo, L.; Meng, L.; Sun, Q.; Ge, Z.; Li, R. RSCAdv., 2014, 4, 6845. https://doi.org/10.1039/c4ra02204a 
16. Le Count, D. J. Comprehensive Heterocyclic Chemistry II Katritzky, A. R.; Rees, C. W.; Scriven, E. F. V., Eds.; Pergamon: Oxford, 1996; Vol. 9, pp 37-39 and references therein.

17. Martinez, R.; Durán, L. M. E.; Cortés, L. C., J. Heterocyclic Chem. 1999, 36, 687.

18. Abd El-Aal, H. A. K. Aust. J. Chem. 2017, 70, 1082. https://doi.org/10.1071/CH17108

19. Roberts, R. M.; Khalaf, A. A. Friedel-Crafts Chemistry: A Century of Discovery Marcel Dekker: New York, NY 1984 and references therein.

20. El-Gazzar, A. R. B. A.; Hussein, H. A. R.; Hafez, H. N., Acta Pharm. 2007, 57, 395. https://doi.org/10.2478/v10007-007-0032-6

21. Puterová, Z.; Andicsová, A.; Végh, D. Tetrahedron 2008, 64, 11262. https://doi.org/10.1016/j.tet.2008.09.032

22. Zhao, Y. L.; Lou, Q. X.; Wang, L. S.; Hu, W. H.; Zhao, J. L. Angew. Chem. Int. Ed. Eng. 2017, 56, 338. https://doi.org/10.1002/anie.201609390

23. Barclay, L. R. C. In Friedel-Crafts and Related Reactions; Olah, G. A. Ed.; Interscience, New York, 1964, Vol. II, Chap. 22, pp 786-960 and references therein.

24. Oulevey, G.; Susz, B. P. Helv. Chem. Acta., 1964, 47, 1828.

https://doi.org/10.1002/hlca.19640470719

25. Oniciu, D. C. In Comprehensive Heterocyclic Chemistry III; Katritzky, A. R.; Ramsden, C. A.; Scriven, E. F. V.; Taylor, R. J. K. Eds.; Pergamon Press: New York, 2008; Vol. 14, pp 1-47 and references therein.

26. Kubo, A.; Saito, N.; Yamato, H.; Masubuchi, K.; Nakamura, M. J., J. Org. Chem. 1988, 53, 4295. https://doi.org/10.1021/jo00253a022

27. Maier, M. E., Angew. Chem. Int. Ed. 2000, 39, 2073. https://doi.org/10.1002/1521-3773(20000616)39:12<2073::AID-ANIE2073>3.0.CO;2-0

28. Yadav, J. S.; Gayathri, K. U.; Subba Redy, B. V.; Prasad, A. R., Synlett 2009, 43. https://doi.org/10.1055/s-0028-1087387

29. Stang, E. M.; White, M. C. J. Am. Chem. Soc. 2011, 133, 14892. https://doi.org/10.1021/ja2059704

30. Ghatak, U. R.; Chakravarty, J.; Banerjee, A. K. Tetrahedron 1968, 24, 1577. https://doi.org/10.1016/S0040-4020(01)82464-9

31. Rueping, M.; Nachtsheim, B. J., Beilstein J Org Chem. 2010, 6, 1. https://doi.org/10.3762/bjoc.6.6

32. Wang, Y. -Q.; Song, J.; Hong, R.; Li, H.; Deng, L., J. Am. Chem. Soc. 2006, 128, 8156. https://doi.org/10.1021/ja062700v

33. Jia, Y. -X.; Zhu, S. -F.; Yang, Y.; Zhou, Q. -L., J. Org. Chem. 2006, 71, 75. https://doi.org/10.1021/jo0516537

34. Poulsen, T. B.; Jørgensen, K. A., Chem. Rev. 2008, 108, 2903. https://doi.org/10.1021/cr078372e

35. Bartoli, G.; Melchiorre, P., Synlett 2008, 1759. https://doi.org/10.1055/s-2008-1078503

36. Yoon, T. P.; Jacobsen, E. N., Science 2003, 299, 1691. https://doi.org/10.1126/science.1083622

37. Alexander, J. B.; La, D. S.; Cefalo, D. R.; Hoveyda, A. H.; Schrock, R. R. J. Am. Chem. Soc. 1998, $120,4041$. https://doi.org/10.1021/ja974353i 